\title{
TOWARDS ZERO-EFFLUENT PULP AND PAPER PRODUCTION: \\ THE PIVOTAL ROLE OF TOTALLY CHLORINE FREE BLEACHING
}

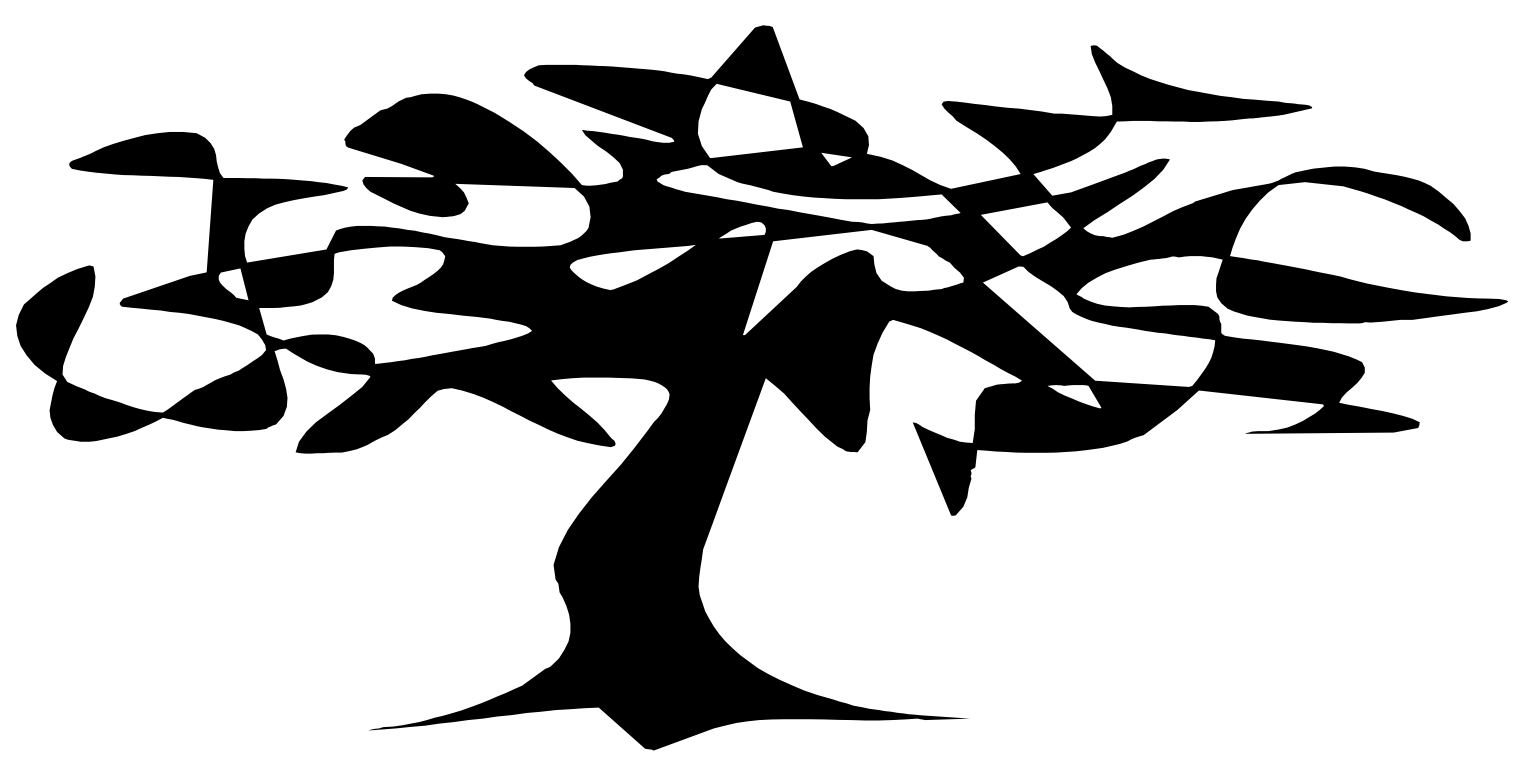

Paul A. Johnston, Ruth L. Stringer, David Santillo, Angela D. Stephenson, Irina. Ph. Labounskaia, Hannah M.A. McCartney, Greenpeace Research Laboratories, Earth Resources Centre, University of Exeter, Exeter, UK.

Technical Report 7/96, November 28, 1996

ISBN 90-73361-32-X

Greenpeace International, Amsterdam 


\section{EXECUTIVE SUMMARY}

The world pulp and paper industry continues to expand production and increasingly, plants are being built in newly industrialised countries. The dominant process is the kraft or sulphate process. Historically, substantial pollution problems have been associated with pulp manufacturing operations. Following the recognition of large scale environmental contamination by organochlorines due to their formation in bleach plants, the industry implemented a number of process internal changes and continued to develop process external treatment processes. The bleach plant of kraft mills generates a substantial proportion of the total process effluents.

The introduction of extended delignification and oxygen delignification can substantially reduce the quantities of lignin entering the bleach plant. Residues from oxygen delignification can be cycled to the recovery process. Overall, this reduces the demand for bleaching agents and hence reduces the generation of organochlorines. Together with substitution of elemental chlorine $\left(\mathrm{Cl}_{2}\right)$ with chlorine dioxide, these systems have substantially reduced levels of AOX being discharged from bleach kraft mills. Organochlorines, however, have not been eliminated from discharges, merely reduced. Swedish research has shown detectable levels of toxicologically chlorinated dioxins and dibenzofurans in the effluents from mills that use chlorine dioxide; so-called elemental chlorine free (ECF) mills.

This stems from the fact that ECF processes are not free of elemental chlorine. Commercial chlorine dioxide generators in many cases co-generate molecular chlorine. Moreover, chemical reactions and $\mathrm{pH}$ dependent chemical equilibria in pulp bleaching reactions involving chlorine dioxide liberate molecular chlorine. This molecular chlorine then reacts with chemicals released from the wood.

Organochlorine production in ECF processes is within a broad range of 0.1-10.0 kg per tonne of air dried pulp produced. The global average is unknown. The improvements engendered by process internal measures are still under investigation. Available results indicate that the greater the degree of chlorine dioxide substitution and early delignification, the better the effluent quality achieved. Many mills, however, have not adopted these stages and therefore discharges of organochlorines are relatively high.

The elimination of organochlorine discharges can be achieved by the use of TCF (Totally Chlorine Free) bleaching where agents such as hydrogen peroxide and ozone are used. A necessary prerequisite of TCF bleaching is a pulp with low residual lignin (kappa number) produced through extended cooking and oxygen delignification. Conversion of existing mills favours this technology over chlorine dioxide based processes in economic terms. In addition the cost of new TCF plant is cheaper than ECF.

In terms of effluent toxicity, TCF systems produce a less toxic effluent than elemental chlorine bleached processes when realistic conditions using actual mill effluents are employed in the experiments as opposed to samples synthesised in the laboratory. Today it is estimated that some 15-20 true TCF mills exist. Recently, however, effects have been identified in fish populations exposed to effluents from pulp mills producing both bleached and unbleached pulp. The chemicals responsible are not removed by advanced secondary treatment and are suspected to be plant sterols or their derivatives which have a strong endocrine disruptive action.

The identification of environmental effects due to both bleached and unbleached pulping activities has led to the concept of the totally effluent free mill. A key impediment to fully closing mill circuits is the difficulty of closure of the bleach lines. Although problems exist with closing both ECF and TCF lines, those involved in closing ECF lines appear to be the most difficult and costly to resolve.

The presence of high levels of chlorides in an acid bleach medium has been associated with severe corrosion problems, and hence the possibility of explosion in recovery boiler systems. Moreover, the presence of organochlorines in both filtrates of ECF bleach liquors and in sludges from treatment plants means that they cannot be incinerated without the emission of products of incomplete combustion including the dioxins and furans (PCDDs and PCDFs). Both closed circuit mills currently operating in Canada are CTMP (chemithermomechanical pulp) mills which do not use chlorine chemicals in the bleach cycle. 
Accordingly, in order to reach likely regulatory standards in the future, closure of mill circuits will be necessary. This is likely to be more easily achievable with TCF technology since there will be a lower requirement for chloride removal from the process liquors. In addition there is much greater potential to deal with these streams without the use of incineration technology. In order to avoid transferring environmental impacts from one medium to another, incineration of ECF derived sludges and other solids will need to be eliminated. Hence, movement of the industry generally into TCF processes rather than ECF systems promises more rapid achievement of the zero discharge goal.

In order to promote sound environmental practice and move towards zero effluent mills, environmental regulators need to promote the need for process changes. Extended cooking and oxygen delignification of pulps is required to reduce the quantities of lignin entering the bleach plant. The bleach plant should be based upon totally chlorine free technologies to reduce effluent toxicity as much as possible and to facilitate water and process chemical recycling without need for incineration of sludge contaminated with organochlorine compounds. Under these conditions, the mill circuits can effectively be closed and operated totally effluent free (TEF). 


\section{INTRODUCTION}

World wide consumption of paper products now exceeds 268 million tons per year (PPI 1995). This is up from 238 million tons in 1990 (PPI 1991) which, in turn, increased from 170 million tons in the late 1970s (Smook 1989). Apparent per capita consumption is greatest in the United States at $332.6 \mathrm{~kg}$ of pulp products, while, by contrast the 1990 figure for Malta was $71.2 \mathrm{~kg}$ and that for India was estimated at $2.7 \mathrm{~kg}$ (PPI 1991). The pulp and paper industry is expected generally to grow significantly in the newly industrialised countries of Africa and Latin America. The highest rates of growth, however, are expected in SE Asia, a premise borne out by the latest world industry figures (PPI 1995). Elsewhere continued growth is also forecast, although at a lower rate than in the past. World consumption is projected to rise to over 310 million tonnes in the year 2000 (Myreen 1994). The changes within the industry are expected to have a significant impact on the chemical industry as well. Some $\mathbf{1 6 . 5}$ million tons of chemicals are used annually in the US and Canadian industries alone. Approximately US\$50 worth of chemicals are used in the production of every ton of bleached softwood pulp, US\$20 per ton of newsprint and US\$80 per ton of reprographic papers (Burt 1987).

The different grades are likely to show differential growth rates but no specific product group is thought likely to disappear from the market. The average composition of products, however, will change. In general, the greater the requirement for fibre purity, the lower the yield of fibre and the greater the cost. Although recycled fibre is predicted to become a major fibre resource with some estimates that it may ultimately comprise $50 \%$ of the total fibre furnish, this is likely to be highly influenced by considerations of energy consumption. The production of mechanical and recycled pulps are energy intensive processes. In addition, (Bystrom \& Lonnstedt 1995), the utilisation rates for waste paper in Europe are already regarded as high, leaving limited scope for the use of waste paper in production. These current general trends are shown in Figure 1. The pulp market overall will be dominated by bleached kraft (sulphate) hardwood and softwood pulps.

Historically, pulp and paper production has long been recognised as a significant point source of pollution. Early control initiatives in the UK, for example, concentrated upon reducing the loading of suspended solids and biological oxygen demand to the recipient (Waldmeyer 1957). BOD control is still problematic in areas where discharges are made to restricted watercourses or enclosed coastal areas. A recent study of the Sone River in India (Srivastava et al. 1988) has shown that the river effectively required $216 \mathrm{~km}$ to revert to its original condition after receiving the effluent from a mill of installed capacity of $85 \mathrm{kt}$ per year. Estimated BOD-7 discharges direct to the Gulf of Bothnia, Gulf of Finland, Baltic Sea and Kattegat totalled some $180 \mathrm{kt}$ per year in the late 1980 s (CGB 1987).

Technologies used or under development at this time included percolating filters, activated sludge processes, anaerobic treatment and high pressure oxidation. These were all broadly end-of-pipe methodologies whose counterparts may be found at many modern mills.

Aerated lagoon systems have to a large extent become the industry standard for wastewater treatment. Process controls, then as now, included fibre recovery systems to reduce loadings of particulates to receiving waters. As in the UK, (Edde 1994) early pollution abatement initiatives in the USA were based largely upon a system of recipient water quality objectives coupled with definition of the notional "assimilative capacity" of the recipient. Subsequently, multi-tiered frameworks of environmental regulation have been evolved in a number of countries (see: Gifford \& McFarlane 1991; Sprague 1991; Edde 1994).

Despite this preoccupation with biological oxygen demand and total suspended solids, however, some early work (eg Ebeling 1931) had remarked on the toxicity of pulp effluents and noted the resinous taste that they imparted to fish flesh. Beginning in the late 1960s there was an increasing awareness of the toxic properties of pulp and paper effluents which had previously been obscured by the excessive BOD demand placed on the receiving waters. The emphasis gradually shifted from unbleached kraft mill wastes to bleached mill wastes and a number of attempts were made to isolate the toxic components. This early work has been comprehensively reviewed by Walden (1976).

As noted by Minor (1982), the pulp and paper industry has had three very difficult problems to 
control as follows: the development of suitable methods for sulphite waste liquor recovery, elimination of malodorous and toxic sulphur compound emissions from the kraft pulping process and the elimination of toxic compounds, BOD, COD and colour from bleach plant effluents. The solution of the bleach plant problems has proven to be the most difficult. Arguably, this aspect of pulp production is the single most important determinant of environmental impact of such operations and the single greatest impediment to reducing and eliminating the environmental impact of pulp production facilities.

Accordingly, this document traces the evolution of bleaching techniques and the problems associated with pulp effluents in receiving waters. It discusses the critical need to modify bleaching processes in order to control more fully process effluents. In particular it examines the use of chlorine dioxide as a substitute for chlorine as a pulp bleach. It reaches the conclusion that if the zero effluent mill is to become a realistic prospect and the industry standard, then all forms of chlorine based bleaching agents need to be substituted for.

\section{PULP PRODUCTION PROCESSES}

Although the history of papermaking dates back to the first century BC (Minor 1982) the modern process dates back to the opening of the Frogmore Mill in England in 1798 (Myreen 1994) producing paper from rags. The extreme short-supply of rags was alleviated in the late 1870 s when it became technically feasible to produce pulp from wood. This was a turning point in the development of the industry which subsequently evolved from an artisanal activity to a fully mechanised industry (Kerski 1995). Subsequently, paper mills came to be located by rivers with afforested catchments, facilitating transport of the mill wood furnish and the use of the rivers for power and process water.

The production of pulp is the single most important technique for the chemical conversion of wood and accounts for more than one third of the total processed mass annually: 460 million cubic metres out of a total 2600 million cubic metres harvested which includes the 1500 million cubic metres used for fuel wood (Fengel \& Wegener 1989). Another perspective is provided by Kerski (1995) who estimates that the annual timber consumption equates to the production of a land area of over 20,000 square kilometres, or around half the area of Switzerland. Pulp and paper production accounts for one per cent of the world's total economic output. The 1992, 1993 and 1994 production figures of the 10 largest pulp producing countries, accounting for around $85 \%$ of the total world pulp production are shown in Table 1 (PPI 1992; 1993; 1994). The rapid and steady increase in demand for pulp products is coupled with an increasing shortage of wood supplies. Hence, short-rotation intensive culture plantations are now being actively researched as a source of mill furnish (Sierra-Alvarez \& Tjeerdsma 1995).

\begin{tabular}{lrrr}
\hline \multicolumn{2}{c}{ Production (x1000t) } & 1994 \\
\hline USA & 1992 & 1993 & $\mathbf{5 8 7 2 4}$ \\
Canada & 59282 & $\mathbf{5 7 0 6 9}$ & $\mathbf{2 4 5 4 7}$ \\
China & 22841 & $\mathbf{2 2 8 9 7}$ & $\mathbf{1 7 0 5 4}$ \\
Sweden & 11985 & $\mathbf{1 5 2 9 0}$ & $\mathbf{1 0 8 6 7}$ \\
Japan & 9589 & $\mathbf{9 9 5 3}$ & $\mathbf{1 0 5 7 9}$ \\
Finland & 11200 & $\mathbf{1 0 5 9 3}$ & $\mathbf{9 9 6 2}$ \\
Brazil & $\mathbf{8 5 2 5}$ & $\mathbf{9 3 3 8}$ & $\mathbf{6 1 0 6}$ \\
CIS & 5368 & 5509 & 3313 \\
France & 6800 & 4365 & 2787 \\
Norway & 2609 & $\mathbf{2 5 4 0}$ & $\mathbf{2 3 4 4}$ \\
\hline
\end{tabular}

Table 1: Pulp production figures for top producers in 1994 as compared to previous years. Data from PPI (1993; 1994; 1995).

Wood is chemically very highly complex. The basic structural element of the cell walls is 
cellulose. Lignin and hemicellulose are also distributed throughout the cell walls, although this distribution is poorly understood (Minor 1982; Fengel and Wegener 1989). The relative proportions vary, but in the cells of Scots pine, the relative proportions are $\mathbf{2 8 . 0}$ weight \% lignin, 28.7 wt $\%$ hemicellulose and 40.3 weight $\%$ cellulose. In addition wood contains $3-10 \%$ of "extractives". This fraction includes fats and esters, terpenes and resin acids, phenolic materials and tannins. Trace quantities of inorganic materials are also present together with heavy metals. The lignin component binds the cellulose fibres together and in order to produce paper the fibres must be separated from each other. This may be achieved mechanically or by chemical dissolution of the lignin.

Pulping is the means whereby the wood is reduced to a fibrous mass for onward processing into paper and board products. After harvesting, the wood is debarked mechanically and converted to chips of specified size. The chips are screened and then pulped. An extensive overview of pulping procedures and treatments is given by Fengel $\&$ Wegener (1989) and Minor (1982) and the reader is referred to these documents for more detailed information. There are a variety of methods for producing pulps mechanically and several chemical pulping methods are in use. Chlor-alkali products are widely used in the refining and bleaching processes involved in the manufacture of chemical pulps. The pulping method of choice will depend upon a number of factors including the grade of paper being manufactured. Different paper qualities utilise different types of fibres. In a copying paper, for example, hardwood fibre is used as the bulk with softwood fibre added to impart mechanical strength. Newsprint is manufactured predominantly of mechanical or recycled fibres with a small component of soft wood fibre to impart strengthening properties.

\begin{tabular}{|c|c|c|c|c|c|c|}
\hline Region & $\mathrm{C}$ & $\mathrm{M}$ & $\mathrm{O}$ & $\mathrm{C}$ & $\mathrm{M}$ & $\mathrm{O}$ \\
\hline & \multicolumn{3}{|c|}{$(1990)$} & \multicolumn{3}{|c|}{ (1994) } \\
\hline $\mathrm{E}+\mathrm{W}$ Europe & 28063 & 14285 & 1711 & 26120 & 13398 & 332 \\
\hline N. America & 62346 & 16310 & 1393 & 67080 & 16189 & 2 \\
\hline L. America & 5700 & 719 & 862 & 8433 & 559 & 626 \\
\hline Asia & 19130 & 2904 & 2444 & 21606 & 3065 & 8089 \\
\hline Australasia & 1270 & 1123 & 0 & 1270 & 1094 & 942 \\
\hline Africa & 1384 & 413 & 592 & 2025 & 504 & 145 \\
\hline TOTAL & 117893 & 35754 & 7002 & 126534 & 34809 & 10136 \\
\hline
\end{tabular}

Table 2: World regional production of pulp by types for 1990 \& 1994. Apparent decline in total figures for Europe is due to closure of plants in the former Eastern Bloc. Data from PPI (1991; 1995). C=Chemical pulp, $M=M e c h a n i c a l ~ p u l p$, O= Other pulp types.

\begin{tabular}{|l|c|c|}
\hline \multicolumn{2}{|c|}{ Production Method } \\
\hline & Million Tonnes & Percentage of Total \\
\hline Sulphate Pulp & $\mathbf{7 2 . 0}$ & $\mathbf{5 8 . 2 \%}$ \\
\hline Sulphite Pulp & 11.4 & $\mathbf{9 . 2 \%}$ \\
\hline Mechanical Pulp & $\mathbf{2 6 . 0}$ & $\mathbf{2 1 . 1 \%}$ \\
\hline Dissolving Pulps & 4.5 & $3.7 \%$ \\
\hline Other Pulps & 9.6 & $\mathbf{7 . 8 \%}$ \\
\hline
\end{tabular}

Table 3. World production of pulp according to pulping method in 1979. Data from Fengel \& Wegener (1979) 


\begin{tabular}{|c|c|c|c|c|c|c|}
\hline \multicolumn{7}{|c|}{ Production (x1000t) } \\
\hline & \multicolumn{2}{|c|}{ Sulphate } & \multicolumn{2}{|c|}{ Sulphite } & \multicolumn{2}{|c|}{ Mechanical } \\
\hline & $\mathbf{B}$ & $\mathbf{U}$ & $\mathbf{B}$ & $\mathbf{U}$ & $\mathbf{M}$ & $\mathbf{S}$ \\
\hline USA & 28249 & 19870 & 1334 & $\mathbf{0}$ & 5338 & 3719 \\
\hline Canada & 10958 & 1474 & 313 & 512 & 10851 & 440 \\
\hline China $^{*}$ & \multicolumn{2}{|c|}{ Total 893} & \multicolumn{2}{|c|}{ Total 89} & \multicolumn{2}{|c|}{ Total 473} \\
\hline Sweden & 4990 & 2048 & 639 & 82 & 2858 & 250 \\
\hline Japan & 6928 & 1638 & 9 & $\mathbf{0}$ & 1636 & 214 \\
\hline Finland & 5157 & 687 & $\mathbf{0}$ & $\mathbf{0}$ & 4181 & - \\
\hline Brazil & 3606 & 1247 & 17 & - & 333 & 37 \\
\hline CIS & 1140 & 866 & 194 & 316 & \multicolumn{2}{|c|}{ Total 915} \\
\hline France & 1025 & 494 & 262 & $\mathbf{0}$ & 886 & 119 \\
\hline Norway & 346 & 162 & 189 & 41 & 1516 & 90 \\
\hline
\end{tabular}

Table 4: Pulp production figures for top producers in 1994 by category of pulp. Data from PPI (1994). B= bleached, U= unbleached, $S=$ semichemical, $M=$ mechanical. Figures for China [*] derived from limited dataset. Disparity between data in Table 1 due to omission of other pulp types and differences in data sources.

All pulping processes are designed to separate the wood fibres present in the wood. Mechanical processes achieve this by grinding or tearing the fibres apart. Chemical processes dissolve the lignin present between the cells allowing the fibres to separate with little or no mechanical action. Techniques available vary between these two extremes. The industry balance of pulping methods is shown in Tables $2 \& 3$ taken from PPI 1991;1995 \& Fengel and Wegener (1989). Table 4 shows the balance of pulping methods used by top producers. The major pulp production methods can be categorised as follows:

\section{1) Groundwood pulping}

These processes essentially grind the raw wood to produce a pulp yield of between 90 and $98 \%$ in modern systems. Modifications to the process include the use of steam as a lignin softening agent and carrying out the process under positive pressure. Uses of this pulp are generally restricted to applications such as newsprint, toilet tissues and paperboard since it tends to yellow on age due to the content of residual lignin.

\section{2) Refiner mechanical pulping}

This process differs from groundwood pulping principally in the use of chips, wafers and sawmill wastes as feedstock. The dominant process is thermo-mechanical pulp where the wood chips are preheated and steamed before being fed to one of the three standard disc-refiner systems. The resulting pulps are somewhat less bright for a given wood species than groundwood pulps.

\section{3) Semi-chemical pulping}

Semi-chemical pulping processes are characterised by a chemical pretreatment stage followed by a mechanical refining step. The process uses predominantly hardwoods and can accommodate wood of relatively inferior quality and wood obtained from mixed stands. The best known of these processes is the neutral sulphite semichemical process and involves impregnation of the chips with sodium sulphite liquor, followed by cooking at 160-190 $\mathrm{C}$ and a subsequent disc refining stage. The pulps produced typically have $10-15 \%$ residual lignin, much higher than the full chemical pulps. The pulps have high rigidity and stiffness and are used in corrugated boards as well as printing papers, greaseproof papers and bond papers. There is no clear demarcation between the semi-chemical processes and the high yield chemical processes which are generally modifications of the normal kraft and sulphite pulping methods.

\section{4) Chemical pulps}

\section{a) Alkaline chemical pulping}

The two major alkaline processes for producing chemical pulps are the alkaline sulphate or "kraft" process and the soda process. In both these processes wood chips are cooked with 
sodium hydroxide in order to dissolve the lignin which binds the fibres together. Sodium sulphide is an additional component of the pulping chemical mix in the kraft process. Both processes are named according to the regeneration chemicals used to compensate for sodium hydroxide: sodium sulphate and sodium carbonate. The kraft process is not only the dominant chemical pulping process but the most important overall in terms of the various production methods. The soda process is important largely in the production of non-wood pulps. Various modifications to the kraft and soda processes have been devised in order to attempt to overcome low pulp yields and environmental problems. These generally involve the addition of chemicals to the digest liquor. The most important of these is anthraquinone (AQ). The benefits of AQ pulping include increased delignification rates together with reduced alkali charges and improved pulp properties.

An integral and economically vital part of alkaline pulping mill operations is the regeneration of the cooking liquors (Fengel \& Wegener 1989; Minor 1982). The recovery cycle is well defined for the kraft process and is designed to recover pulping chemicals, reduce water pollution by combusting organic matter in the spent liquor, generate process heat and recover by-products of value. The main steps in the process are the evaporation of the black liquor drained from the digester after wood chip digestion, combustion of the concentrated liquor to produce a mineral "smelt", causticisation of the smelt and regeneration of the lime used in the process. The energy content of the black liquor is high. Gullichsen (1991) notes that half of the wood is dissolved during the manufacture of chemical pulp, and this, when combusted in the recovery boiler, provides heat for the plant systems.

The heart of the process is the recovery furnace. The black liquor is evaporated to a solids content of between $60 \%$ and $75 \%$ using a 5-6 stage system and this is followed by direct contact evaporation in which flue gas from the recovery boiler is brought directly into contact with the liquor. Tall oil soaps are recovered during the evaporation stages. Oxidation of the liquor prior to evaporation can be carried out to reduce the emission of malodorous compounds. When the black liquor is concentrated, sodium sulphate and other chemicals are added to compensate for those lost in the pulping process.
In the recovery boiler, the organic content is combusted to produce heat. Carbon dioxide reacts with sodium hydroxide to produce sodium carbonate. The added sodium sulphate is reduced to sodium sulphide and hence the solid smelt produced by the boiler contains largely sodium carbonate and sodium sulphide. This is dissolved in a tank to produce the green liquor which is subsequently filtered and treated with calcium hydroxide (slaked lime) to convert the sodium carbonate to sodium hydroxide. The resulting white liquor is then returned to the digestion process. The lime is regenerated by heating and mixing with water removed from the green liquor. This process is, therefore, theoretically closed in relation to water use but not with respect to atmospheric emissions, spills and condensate generation.

The pulps produced by the kraft process are characterised by good strength properties. They are, therefore, the preferred grades in strong paper grades such as the liner in corrugating boards or bag and wrapping papers. Hardwood kraft pulps are used in many printing papers for bulking purposes, in mixture with softwood pulps. The residual lignin present in the pulp is expressed in terms of the "kappa number" which is determined by the oxidation of lignin by potassium permanganate under acidic conditions. The lower the kappa number of a pulp, the lower the level of residual lignin.

\section{b) Sulphite chemical pulping}

The basic processes for the manufacture of sulphite chemical pulps are outlined by Fengel and Wegener (1989) and Minor (1982). These are the acidic sulphite process, bisulphite process, multi-stage sulphite process, neutral sulphite process and alkaline sulphite process. All are described in terms of the composition of the cooking liquor which in turn defines the process pH and the choice of basic chemicals used. The gas sulphur dioxide is used to generate the sulphite chemicals used in digestion. Pulping conditions vary widely according to the mill furnish and the different processes produce pulps of differing chemical composition and papermaking application.

Sulphite pulps are a relatively small component of the pulps produced globally in relation to kraft, semichemical and mechanical pulps as shown by the data in Table 4 derived from PPI (1994). 


\section{d) Organosolv pulping}

This pulping method has been receiving increased attention in recent years. Solvent pulping offers a number of potential advantages over conventional pulping techniques such as relatively low chemical and energy consumption coupled with low capital costs and low environmental impact. Aqueous organic solvents such as methanol and ethanol are used for delignification to produce a bleachable pulp which can be bleached with non-chlorine chemicals. Pilot scale tests have given high pulp yields with strength properties similar to sulphite

and kraft pulps (see: Sierra-Alvarez \& Tjeerdsma 1995).
Water is an important consumable in the production of pulp and paper. With time, however, there has been a progressive reduction in the use of water at mills (Edde 1994) considered in relation to all types of mill. Whereas in $\mathbf{1 9 5 9}$ around 240 cubic metres of water were used in the production of 1 tonne of air dried pulp, by 1988 average water usage had been reduced to 72 cubic metres per air dried tonne. The most recent technology, installed in South Africa, has a water demand of $16 \mathrm{~m}^{3}$ per air dried tonne. Table 5 shows the main sources of aqueous effluent produced in a bleached kraft mill.

\section{WATER USE}

\begin{tabular}{|c|c|c|c|c|}
\hline \multicolumn{2}{|c|}{ Process Area } & Newer Mills & Current designs & Possible Future \\
\hline \multicolumn{2}{|l|}{ Woodroom } & 0.3 & 0.3 & 0.3 \\
\hline \multicolumn{2}{|l|}{ Digestion } & 1.0 & 1.0 & 0.2 \\
\hline \multicolumn{2}{|c|}{ Washing \& Screening } & 1.8 & 0.5 & 0.2 \\
\hline \multirow[t]{2}{*}{ Bleach Plant } & - Acid & 21.1 & 10.5 & 5.3 \\
\hline & - Alkaline & 10.0 & 10.6 & 5.3 \\
\hline \multirow[t]{2}{*}{ Pulp Machine } & - Rejects & 1.3 & 0.7 & 0.3 \\
\hline & - General & 5.9 & 5.9 & 0.7 \\
\hline \multirow{2}{*}{\multicolumn{2}{|c|}{$\begin{array}{l}\text { Evaporators } \\
\text { Demineralisation }\end{array}$}} & 0.6 & 0.4 & 0.2 \\
\hline & & 0.1 & 0.1 & 0.1 \\
\hline \multicolumn{2}{|l|}{ Recovery } & 0.7 & 0.2 & 0.2 \\
\hline \multicolumn{2}{|c|}{ Hog/Power Boiler } & 3.3 & 1.0 & 0.5 \\
\hline \multicolumn{2}{|c|}{ Recausticising } & 1.4 & 1.1 & 0.5 \\
\hline \multicolumn{2}{|c|}{ Chemical Preparation } & 0.8 & 0.3 & 0.2 \\
\hline \multicolumn{2}{|c|}{ Water Supply } & 8.1 & 2.7 & 0.8 \\
\hline \multicolumn{2}{|c|}{ Effluent Treatment } & 0.0 & 1.2 & 0.2 \\
\hline \multicolumn{2}{|c|}{ Clear water by-pass } & 16.6 & 0.0 & $\mathbf{0 . 0}$ \\
\hline \multicolumn{2}{|l|}{ TOTAL } & 73.0 & 36.5 & 14.8 \\
\hline
\end{tabular}

TABLE 5 Effluent arisings from various mill processes with various design concepts. All figures in cubic metres per tonne of air dried pulp.

Various stages of the pulping process give rise to aqueous effluents in kraft mills. Comparative water usages at given stages and states of technology for bleached hardwood kraft pulp are given by Edde (1994) and these figures are reproduced in Table 5. These demonstrate quite clearly that whatever the design, the bleach plant effluents comprise a highly significant proportion of the total process effluent arisings. In the case of advanced future designs, the bleachery effluent will make up $71 \%$ of the effluent flow although the total volume generated per tonne of air dried pulp could be around a third of current levels.

Projected reductions in effluent arisings are likely to be achieved by extensive internal collection and recycling, and the diversion of some process effluents to feed other parts of the production cycle (Edde 1994). One of the key factors on which this depends is the quality of bleachery effluents and the degree to which they can be reused within the process and minimised in volume. Since 
chlorine and chlorine-chemical bleaching agents produce an effluent high in chloride they cannot be readily processed through the recovery cycle. The chloride ion, as hydrochloric acid is highly corrosive, giving the potential for leakage from the boiler tubes and the risk of serious explosion if water reaches the melt of minerals in the bottom of the boiler (McDonough 1992).

As noted by Albert (1995a) the only reason that process effluents are generated from a bleached kraft mill is due to the need to purge dissolved and suspended materials from the system which would otherwise inhibit production or affect product properties. If these can be dealt with through internal measures then closure of mill circuits and reduction of effluent volumes becomes feasible.

\section{BLEACHING AGENTS and PROCESSES FOR CHEMICAL PULPS}

The whiteness of produced pulp has traditionally been regarded as an index of quality not only within the industry, but also by the consumer. The whiteness of pulp is measured by its ability to reflect monochromatic light in comparison to a known standard, usually of magnesium oxide. Unbleached pulps exhibit a wide range of brightness values. Kraft pulp is generally dark brown in colour while sulphite pulps are a light yellow-brown.

The principal aim of pulp bleaching is to increase the brightness of the pulp. The chromophoric (light absorbing) components in pulps are predominantly functional groups of degraded and altered residual lignin which is both darker and more tightly bound to the fibres than the original lignin component (McDonough 1992). This can either be converted and stabilised (lignin preserving bleaching) or removed (lignin removing bleaching). In the production of dissolving pulps, the bleaching stage is also regarded as part of the refining process, helping to produce a pure pulp with high alpha-cellulose content. In the less highly refined pulps, bleaching is regarded as removing wood extractives and bark specks, and conferring superior strength characteristics. Mechanical pulps are bleached using oxidative chemicals, predominantly hydrogen peroxide.

The chemical pulps are generally bleached using a multistage process of three to six steps, depending upon the pulp characteristics. Hardwood pulps generally require less bleaching than softwood pulps since they have a lower lignin

\begin{tabular}{lll}
\hline Stage & $\mathrm{Chemicals} \mathrm{Used}$ & Symbol \\
\hline Chlorine & $\mathrm{Cl}_{2}$ & $\mathrm{C}$ \\
Alkaline extraction & $\mathrm{NaOH}$ & $\mathrm{E}$ \\
Hypochlorite & $\mathrm{NaOCl}+\mathrm{NaOH}$ & $\mathrm{H}$ \\
Chlorine Dioxide & $\mathrm{ClO}_{2}$ & $\mathrm{D}$ or $\mathrm{P} / \mathrm{E}$ \\
Peroxide & $\mathrm{Na}_{2} \mathrm{O}_{2}+\mathrm{NaOH}$ & $\mathrm{P}$ or $\mathrm{P} / \mathrm{E}$ \\
& $\mathrm{H}_{2} \mathrm{O}_{2}+\mathrm{NaOH}$ & $\mathrm{O}$ \\
Oxygen & $\mathrm{O}_{2}+\mathrm{NaOH}$ & $\mathrm{C}$ \\
Chlorine/ $\mathrm{ClO}_{2}$ & $\mathrm{Cl}_{2} / \mathrm{ClO}_{2}$ & $\mathrm{D} / \mathrm{C}$ \\
Sequential Bleach & $\mathrm{ClO}_{2} / \mathrm{Cl}_{2}$ & $\mathrm{C} / \mathrm{H}$ \\
& $\mathrm{Cl}_{2} / \mathrm{NaOCl}^{2} \mathrm{NaOH}$ & $\mathrm{D} / \mathrm{H}$ \\
Mixed Bleach & $\mathrm{ClO}_{2} / \mathrm{NaOCl}+\mathrm{NaOH}$ & $\mathrm{C}+\mathrm{D}$ \\
Low level chlorine & $\mathrm{Cl}_{2}+\mathrm{ClO}_{2}$ & $(\mathrm{C})$ \\
Gas phase bleaching & $\mathrm{Cl}_{2}$ & $\mathrm{C}$ \\
& $\mathrm{Cl}_{2}$ & $\mathrm{D}$ \\
Ozone & $\mathrm{ClO}_{2}$ & $\mathrm{Z}$ \\
Acid & $\mathrm{O}_{3}$ & $\mathrm{~A}$ \\
\hline
\end{tabular}

TABLE 6. Bleaching chemicals and process short hand nomenclature from Fengel \& Wegener (1989). 


\begin{tabular}{|c|c|}
\hline Pulp Type & Sequence \\
\hline \multicolumn{2}{|l|}{ Sulphite and Bisulphite Pulp } \\
\hline 3-Stage & C-E-H \\
\hline \multirow{9}{*}{ 4-Stage } & C-E-H-H \\
\hline & C-E-H-D \\
\hline & C-E-D-H \\
\hline & C-C-E-H \\
\hline & C-H-E-H \\
\hline & H-C-E-H \\
\hline & C-E-D-D/H \\
\hline & C+D-E-H-D \\
\hline & E-C-H-D \\
\hline \multirow[t]{2}{*}{ Five Stage } & C-E-H-D-H \\
\hline & C-C-E-H-H \\
\hline \multicolumn{2}{|l|}{ Kraft Pulp } \\
\hline \multirow{2}{*}{ Three stage semi-bleached } & C-E-H \\
\hline & D/C-O-D \\
\hline \multirow{9}{*}{ Four stage part semi-bleached } & C-E-H-D \\
\hline & C-E-H-P \\
\hline & C-E-H-H \\
\hline & C-H-E-H \\
\hline & C-D-E-D \\
\hline & O-C-E-H \\
\hline & O-C-E-D \\
\hline & O-D-E-D \\
\hline & O-D-O-D \\
\hline \multirow{9}{*}{ Five Stages } & C-E-H-P-D \\
\hline & C-E-H-D-P \\
\hline & C-E-H-E-H \\
\hline & C-E-D-E-D \\
\hline & C-E-D-P-D \\
\hline & C-E-H-E-D \\
\hline & C-H-D-E-D \\
\hline & D-E-D-E-D \\
\hline & C-C/H-E-H-H \\
\hline \multirow[t]{10}{*}{ Six Stages } & C-H-E-D-E-D \\
\hline & C-E-H-D-E-D \\
\hline & C-E-H-E-H-D \\
\hline & C-E-H-D-P-D \\
\hline & C-E-H-E-D-P \\
\hline & C+D-E-H-D-E-D \\
\hline & O-C-E-D-E-D \\
\hline & O-C+D-E-D-E-D \\
\hline & O-D-E-D-E-D \\
\hline & O-C-D-E-H-D \\
\hline Seven Stages & C-H-H-D-D-D-P \\
\hline
\end{tabular}

TABLE 7. Established pulp bleach sequences showing the predominant role of $\mathrm{Cl}_{2}$ and $\mathrm{ClO}_{2}$ in the industry. 


\begin{tabular}{|c|c|}
\hline Application & Bleach Sequence \\
\hline Reduced Chlorine & $\begin{array}{l}\text { (C)-P-H } \\
\text { (C)-P-D-H } \\
\text { (C)-P-H-D-H }\end{array}$ \\
\hline Peroxide replacement & $\begin{array}{l}\text { P-D-P } \\
\text { P-D-H } \\
\text { P-H-H } \\
\text { P-H-D } \\
\text { D-P-D } \\
\text { P-H-D-H } \\
\text { P-D-P-D }\end{array}$ \\
\hline Oxygen Bleaching & $\begin{array}{l}\text { O-P } \\
\text { O-D } \\
\text { O-H } \\
\text { O-P-D } \\
\text { O-D-P } \\
\text { O-C-P } \\
\text { O-H-P } \\
\text { O-C-P-D } \\
\text { O-D-P-D } \\
\text { O-C C-E-D } \\
\text { O-D } \\
\text { O-E-D }\end{array}$ \\
\hline Ozone Bleaching & $\begin{array}{l}\text { Z-E-P } \\
\text { Z-E-Z } \\
\text { Z-E-Z-P }\end{array}$ \\
\hline Peracaetic acid & $\begin{array}{l}\text { P-A-P } \\
\text { A-E-A-E-A }\end{array}$ \\
\hline Others & $\begin{array}{l}\text { OQP } \\
\text { OQPP } \\
\text { OQPZP }\end{array}$ \\
\hline
\end{tabular}

TABLE 8. Pulp Bleach Sequences designed to reduce or eliminate the use of chlorine based compounds and chlorine from Fengel \& Wegener (1989).

content. Sulphite and bisulphite pulps are more easy to bleach than kraft pulps, and can be manufactured entirely without bleaching with chlorine or its compounds although chlorine bleaching is used. The following text, therefore, largely considers the bleaching of kraft pulps which is the dominant production process on a global basis.

The historical use of bleaching chemicals in the pulp industry parallels their use in textile bleaching applications. In part this is due to early paper being manufactured from rags. The early bleaching of paper manufactured from non-wood fibres was carried out using sunlight (Farr et al. 1992). At the end of the 19th century, hypochlorite was introduced, and later elemental chlorine. In some cases, a combination of these chemicals was used and generally, an intermediate alkaline lignin extraction step was introduced (Fengel \& Wegener 1989). Some commonly used bleach sequences together with the identifying keys used, are given in Tables 6, 7 \& 8.

Table 6 shows the key role of chlorine and 
chlorine chemicals in traditional bleach sequences in the form of elemental chlorine or as chlorine dioxide and hypochlorite. Common industrial bleaching sequences are shown in Table 7. Table 8 shows non-traditional sequences which are designed to reduce or replace chlorine. Historically, in most commercial bleaching processes, chlorine bleaching is the first step carried out at a level of $3-4 \% \mathrm{Cl}_{2}$ at $20-40^{\circ} \mathrm{C}$ for 30-60 minutes The residual lignin is converted to water- and alkali- soluble degradation products by the chlorine. This step is generally followed by an alkaline extraction step to remove these components. The final process steps involve the use of hypochlorite or chlorine dioxide.

Chlorine dioxide, despite handling difficulties, is largely replacing elemental chlorine in the initial bleaching stages. Its perceived advantages are: higher pulp brightness, improved fibre strength properties, lower chemical consumption and considerable reduction in the AOX of discharged effluents. Peroxide in combination with chlorine dioxide is often used in the later stages of bleaching chemical pulps.

Chlorine gas became a common bleaching agent in the first thirty years of the twentieth century (Reeve 1996). In conventional bleaching processes around $90 \mathrm{~kg}$ of chlorine was used per tonne of pulp produced. This figure is stated to have now been reduced to around $25 \mathrm{Kg}$ per tonne and often to around 3-10 kg/tonne (RSAES 1989) although Kringstadt \& Lindstrom (1984) state the chlorine charge to the pulp slurry to be between 60 and 70 kg per tonne of produced pulp. Chlorine dioxide was first used on a large scale in the 1940's and was first used in Sweden in 1947. This led to the multi-stage CEDED bleaching sequence which allowed high brightness products from kraft pulp without the loss of strength. The evolution of bleaching techniques has followed pulping process developments to a very large extent. In particular, the chemicals applied have changed as the lignin content of the pulps entering the bleach sequence has been reduced.

The historical aspects of bleaching developments are traced by Sodra-Cell (1996). A key factor was the development of oxygen bleaching in the process during the 1970 's followed by use of oxygen in the alkaline extraction stages a decade or so later. Oxygen bleaching was inserted as a step after the digestion stage and allowed the lignin content of the pulp entering the bleach plant to be reduced from on average $5 \%$ to $2.5 \%$. This effectively halved the potential problem from the bleach plant effluent. In addition, extended cooking time of the pulp in the digester also reduced the quantities of lignin entering the bleach plant and this was commercially demonstrated in the $1980 \mathrm{~s}$.

Substantial substitution of chlorine dioxide for chlorine has been known since the 1960's but became widely accepted during the 1980 's as a result of growing concerns about the environmental impacts of organic chlorine compounds formed during chlorine bleaching. Complete substitution led to elemental chlorine free processes (ECF) becoming dominant first in Sweden and then in Canada and this is widely attributed to market pressures. Even so, cost considerations, particularly in the US appear to have inhibited the application of chlorine dioxide. Chlorine dioxide is relatively more expensive than chlorine with respect to the bleaching power per unit mass. Further development led to bleaching processes that did not use chlorine based chemicals (totally chlorine free or TCF). Development of hydrogen peroxide and ozone bleaching technology was an essential prerequisite of the commercial feasibility of such methods.

Overall, various bleach sequences have been employed with varying degrees of chlorine substitution. Moreover, variation in the base technology means that a wide range of ECF processes in particular exist. This point is discussed further below.

\section{FORMATION OF ORGANOCHLORINES BY CHLORINE BLEACHING}

Due to the complexity of pulp mill discharges in chemical terms, it has become common to use various group parameters to characterise them. In addition to COD (chemical oxygen demand) and biological oxygen demand (BOD) the parameter of $\mathrm{AOX}$ is used to measure the quantities of organohalogens. AOX denotes adsorbable organohalogen compounds and the term adsorbable refers to the measuring technique used where the chemicals are adsorbed onto activated carbon before quantification by a combustion technique. Broadly, where chlorine chemicals are used, the quantity of AOX 
generated in $\mathrm{kg}$ per tonne of air dried pulp conforms to the following approximation:

$$
\mathrm{AOX} \approx 0.1\left(\mathrm{Cl}_{2} \text { charge }+\mathrm{ClO}_{2}\right. \text { charge/5) }
$$

Considerable research effort has been expended on the detailed characterisation of pulp bleach liquors, a process only partly helped by advances in analytical techniques such as GC/MS (gas chromatography/mass spectrometry). This has shown effluents from pulp and paper bleach plants using chlorine to be extraordinarily complex. Suntio et al. (1988) published a compilation of over 250 chemicals present in pulp mill effluents. 180 of those listed are chlorinated compounds comprising phenolic, together with neutral and acidic compounds. The chlorophenolic compounds, particularly chlorophenols, catechols, guaiacols and syringols are important components and have, for example, been isolated from samples taken in every sub-basin of the Baltic Sea (Sodergren 1993). A proportion of these compounds appear to be derived from the degradation of high molecular weight chlorinated material formed during chlorine bleaching (Martin et al. 1995). It is only recently that reference compounds for some of these exotic chemicals have been synthesised for analytical purposes (Smith et al. 1994 a \& b; Hyotylainen 1994).

Buser et al. (1989) identified a series of methyl-, polymethyl- and alkyl-polychlorodibenzofurans in pulp mill sludge and sediment which had previously been misidentified as polychloroxanthones and polychloro-xanthenes. van Loon et al. (1990) have described the analysis of chlorolignins in pulp mill effluent, although these were not quantified. A significant component of the high molecular mass compounds was identified as chlorolignosulphonic acids by van Loon (1992) in effluents discharged to the River Rhine. Chlorinated diones and enol lactones with mutagenic properties have been identified (McKague et al. 1988) while subsequent studies (McKague et al. 1989) have revealed the presence of trichlorothiophenes, compounds with significant potential for bioaccumulation. McKague et al. (1990) also identified chloroacetones at a number of mills. Low chlorinated PAHs present in pulp effluents were isolated by Koistinen et al. (1992).
Elemental chlorine reacts primarily with residual lignin to produce approximately $4 \mathrm{~kg}$ of organically bound chlorine per tonne of pulp produced, although this figure will vary according to the kappa number of the pulp being bleached and the specific bleach sequence. Various types of reaction mechanism can be involved and the diversity of such reactions is usefully described by Bergman et al. (1994). About 70\% of the organically bound chlorine is present as high molecular mass material in spent liquor from the bleach. In the extraction liquor about $95 \%$ is bound as high molecular mass compounds with high carbon to chlorine ratios. Although these are thought, in themselves, to be biologically and toxicologically inactive, no data exist concerning the activity and fate of their degradation products. In addition, their high relative molecular mass coupled with their polarity renders them difficult to analyse by established chromatographic techniques (Kringstadt \& Lindstrom 1984).

Around $30 \%$ of the organically bound chlorine is found in the spent chlorination liquor and $5 \%$ in the alkali extraction liquor as compounds of low molecular mass. Quantitatively, the most important is trichloromethane which may be produced in quantities of up to $40 \mathrm{~g}$ per tonne of produced pulp. Trichloroethene, pentachlorobenzene and dichlorophenol are also produced in significant quantities together with a number of chlorinated phenolic compounds. Kallqvist et al. (1989) reported emissions of $5.7 \mathrm{~kg} /$ hour of dichloromethane and $0.47 \mathrm{~kg} / \mathrm{hour}$ trichloromethane from one pulp mill studied. A total of $119 \mathrm{~g} /$ hour of various chlorophenolic compounds were also emitted. The derivatisation of pulp and paper effluent phenolics for analytical purposes is described by Lee et al. (1989) who considered the routine monitoring of these compounds to be important.

The biological impact of many of these chemicals remains unknown. There is now considerable 
evidence that metabolism and degradation of pulp mill derived organochlorines can considerably complicate an already complicated picture. For example, in a study of organochlorines accumulated by mussels in a bleach plant recipient at levels of $2045 \mathrm{ug} / \mathrm{g} \mathrm{AOX}$ in the lipid fraction, only $1.1 \%$ could be related to identified organochlorines (Pellinen et al. 1994). Other work (Wesen et al 1990) demonstrated that between 10 \& $15 \%$ of EOCl in fish can be related to known compounds while in sediments the figure is nearer $5 \%$. It is thought that in fish, large amounts of chlorine may be present in the form of chlorinated fatty acids whose origin is not known but may result from biological transformations of more complex chlorinated organic molecules.

Chlorinated phenols are known precursors of the polychlorinated dibenzo-p-dioxins (PCDDs) and the dibenzofurans (PCDFs). Consequently, the discovery of the chlorinated phenols in spent bleach liquor has led to pulp and paper plants being identified as sources of the highly toxic and bioaccumulative PCDDs and PCDFs. The industry is widely acknowledged to be one of the major sources for the contamination of aquatic systems in N. America and Scandinavia where most research has been carried out into the bleaching of pulp using chlorine compounds (Swanson et al. 1988; Whittemore et al. 1990). In addition to the chlorophenolics derived from wood, oil based defoamers have also been identified as precursor materials (see: Servos et al. 1995). The congener of principal interest is 2,3,7,8-tetrachlorodibenzo- -p-dioxin. This is the most toxic congener but other members of the group are also formed by chlorine bleaching. A study of a New Zealand wood processing facility (Campin et al. 1991) clearly demonstrates the role of chlorine bleacheries in the overall mass balance of PCDDs and PCDFs. In addition, contamination of the site with pentachlorophenol, originally used for sapstain control, was also identified as contributing to the overall dioxin loading to the receiving ecosystem.

Estimates made of organochlorine discharges from the Swedish industry in the 1980 s, before process changes to ECF and TCF were widely implemented indicate that the quantities were extremely large. Wigilius et al. (1988) estimated that Swedish kraft mill effluents contained around $200 \mathrm{kt}$ of organochlorines corresponding to approximately 15kt of bound chlorine. It can been estimated on this basis that $5 \mathrm{~kg}$ organically bound chlorine produced per tonne of pulp corresponds to a potential global discharge of 250kt of AOX. The actual mass of compounds discharged will be somewhat higher since empirical formulae range from $\mathrm{C}_{9} \mathrm{H}_{9} \mathrm{O}_{4} \mathrm{Cl}$ to $\mathrm{C}_{14} \mathrm{H}_{10} \mathrm{O}_{8} \mathrm{Cl}$. Hence the chlorine comprises a low proportion of the relative molecular mass. On the basis of the Swedish figures, 250kt of organically bound chlorine represents around $3000 \mathrm{kt}$ of organochlorine compounds. This, of course, represents a worst case scenario. Nevertheless, the perceived improvements in developed nations must be considered alongside the growth of pulping in developing countries where elemental chlorine is still very widely used.

Evidence mounted throughout the 1980s that mill discharges were responsible for increasing levels of organochlorines detected in receiving environments and a variety of ecological effects ranging from lethal effects upon marine macroflora to deformities and physiological abnormalities in fish. This led to a number of comprehensive and case specific studies being carried out (see: Sodergren \& Wartiovaara 1988; Sodergren 1989; Sodergren 1993; Lindesjoo 1992; Forlin et al. 1995). These broadly confirmed the extent and scale of the ecological impacts of bleachery effluents from pulp mills and became highly influential in the formulation of regulatory policy worldwide. It has been estimated (Wulf \& Rahm 1993) that around half the organochlorines produced by the Baltic pulp industry since the 1940s are still present in the sediments of the region.

In the North American industry, analysis of pulp mill wastes showed significant levels of chlorinated dioxins to be present. In bleached kraft pulp samples 2,3,7,8-TCDD and TCDF were found at levels ranging between 1-51 parts per trillion and 1.2-330ppt respectively. Primary sludge content ranged between 3.3 and $180 \mathrm{ppt}$ TCDD and 34-180 ppt TCDF. Levels in final effluent ranged between 3-120 parts per quadrillion for TCDD and between 7-2,200 ppq for TCDF (see: Harriman Chemsult 1989).

Bioaccumulation of the chlorinated dioxins and dibenzofurans in commercially important aquatic species led to the closure of several fisheries in Canada in late 1988 (Hocking 1991). The potential importance of local discharges upon fisheries and fish consumers may be assessed from the work of Svensson et al. (1991). They found 
that subjects graded as having a high fish consumption had blood levels of dioxins around three times higher than average consumers. The scale of the problems encountered is reported by Whittle et al.(1993). A case specific US study is described by Schell et al. (1993) while bioaccumulation of dioxins in a Canadian river system is described by Owens et al. (1994).

As a result of the complexity of bleachery effluents in relation to their organochlorine content, there has been a trend towards monitoring their discharge by means of the group parameter AOX. AOX (Adsorbable Organic Halogens) measures the quantity of organically bound chlorine present in a sample. While useful as a process control monitoring index, it has important limitations which prevent its use as a predictor of environmental impact. The most obvious is simply that it gives no indication of the nature of the substances present (see eg Folke 1991; Neilson et al. 1991). Nonetheless, this parameter is a widely used index of the quality of pulp mill effluents.

\section{POLLUTION CONTROL MEASURES}

In the face of growing political and public concern, the pulp and paper industry began to research and implement ways of reducing organochlorine formation and discharge from mills reported as $\mathrm{AOX}$ in addition to $\mathrm{COD}$ and BOD discharges. These can be broadly categorised as process internal and process external measures.

\section{a) Process Internal Measures}

Various process modifications have been implemented by the industry to reduce and contain spills arising from pulping and chemical recovery operations and these also lead to economic benefits by reducing chemical losses (Downs 1989). Nonetheless, these measures do not address the problem of bleachery effluents which account for a substantial proportion of total mill effluents.

Process internal measures to reduce mill organochlorine and other polluting outputs centre around increased removal of lignin before the pulp is sent to the bleach plant (see: Gullichsen 1991; McDonough 1992). Enhanced lignin removal allows modification of the bleaching process and agents and reduces the charge of bleaching chemicals used. In turn, this positively affects most bleach plant effluent quality indices, including BOD, COD, Colour and AOX. In part this can be achieved by improved washing of the brown pulp at various intermediate stages (brownstock washing). This gives a lower loss of lignin into the bleach plant. This is particularly true of washing after extended and oxygen delignification stages. In these cases the lower lignin content makes lignin removal of greater relative importance.

\section{i) Extended delignification}

The degree to which lignin can be removed by extended cooking of the woodchips alone is limited. Over cooking results in a reduction of the strength qualities of the pulp (Minor 1982; Fengel \& Wegener 1989). While AQ pulping with anthraquinone as an additive allows cooking to lower kappa numbers without loss of pulp quality, the additive is expensive and this has restricted its use. Extended delignification without strength loss can be achieved by ensuring that the alkali concentration stays as constant as possible throughout the cook (Gullichsen 1991). Using methods such as Modified Concurrent Countercurrent (MCC) cooking or Rapid Displacement Heating (RDH) the lignin content of softwood kraft pulp can be reduced from $5 \%$ to less than $4 \%$.

\section{ii) Oxygen delignification}

The use of oxygen in combination with alkali was first practised commercially in 1970 (McDonough 1992). It was first used in a pre-delignification stage to remove about half of the lignin from unbleached pulp. A great advantage of this process, is that unlike chlorine based bleach effluents, the effluent can be recycled, concentrated and sent to the chemical recovery system (Albert 1995a). This procedure is now widespread: most new mills and mill expansions include it while the use of oxygen to enhance the effectiveness of the first caustic extraction stage is regarded as almost universal.

Delignification is generally limited to between 40 \& $50 \%$ since oxygen lacks the selectivity needed to take the process further. Accordingly, research has been directed at developing chemical pretreatments to improve oxygen selectivity and hence avoid pulp strength loss. An example is the 
PRENOX process (Gullichsen 1991), although this has not evolved to the stage of commercial development and application. Oxygen has become one of the main delignification technologies after steady growth during the 1980's and early 1990's (Hassi 1993) and according to industry figures (see: Reeve 1996 a \& b) by 1994 some $50 \%$ of world capacity for kraft pulp incorporated an oxygen delignification stage. According to these figures proportional penetration of this technology is significantly less in the USA and Canadian industry as compared to the Scandinavian industry.

Improved delignification processes allow modification of the subsequent bleach sequence by reducing the quantities of chemicals required to produce pulps of the commercially requisite brightness.

\section{iii) Modification of the Bleach Process}

The second major area of process internal measures designed to reduce organochlorine generation is modification of the bleach sequence. Most organochlorines are formed in the bleach plant due to the action of molecular chlorine. Hence, elimination of its use will significantly reduce their formation. In 1990 , chlorine used in pulp and paper treatment accounted for $5 \%$ of total chlorine use in Western Europe. Current figures suggest that in combination with water treatment, this sector accounts for around $2 \%$ of production. Over a similar time period, elemental chlorine use has fallen from $20 \%$ to $13 \%$ of the total chlorine market in the US reflecting similar, although markedly less pronounced, trends (Shelley 1990; Botha 1995).

Essentially, elemental chlorine has disappeared from use in Scandinavia. Bergman et al. 1994 state that it is no longer used in Sweden, although they note that large quantities are still used for pulp production in the US. Albert (1995a) notes that currently over 50 bleached kraft pulp mills worldwide are producing pulp without the use of elemental chlorine (ECF) and some 10 kraft plants are producing pulp without the use of chlorine chemicals (TCF). Albert (1994) lists over sixty mills producing TCF pulp. These figures, however, include sulphite and CTMP lines as well as kraft mills. The latest figures suggest that some 15-20 TCF kraft mills exist but not all are fully converted and use chlorine dioxide as a bleach agent on occasion.
Elemental chlorine use has been substituted to varying extents by chlorine dioxide in bleach plants. According to McDonough (1992) substitution of elemental chlorine by between 50 \& $70 \%$ chlorine dioxide has been practised for a long time but in relatively few mills. Chlorine dioxide has also been used widely in the final brightening stages of pulps at concentrations of between 0.1 and $1.2 \%$. Figures provided by Gullichsen (1991) indicate that chlorine dioxide substitution of $90 \%$ will lead to AOX discharge levels equal to those achieved by extended delignification, oxygen and effluent treatment. Overall, in combination, these process modifications mean that whereas traditional processes discharge 5-10 $\mathrm{kg}$ of $\mathrm{AOX}$ per tonne of air dried pulp, mills may now discharge $1.5 \mathrm{~kg}$ AOX/ADT.

The term ECF can embrace a wide range of process technologies. This has led to considerable confusion and debate in the technical literature as to the relative merits of ECF and TCF in environmental and marketing terms. A good example of poor use of data is furnished by AET (1996). The data show that ECF pulp production is rising faster than for any other sector in the pulp industry and provides various quotes demonstrating that market demand for TCF is limited, and that the environmental impacts are equal to those of TCF. The counter argument is given by Gunnarsson (1995). This turns upon the fact that as of 1994 more than $\mathbf{5 0}$ mills of a total of 87 in the US were using old pulping technology without extended cooking and oxygen delignification.

Hence, the term ECF is often applied both to pulp with a high kappa number likely to generate large quantities of AOX and that produced with a low kappa number, implying that much less AOX would be formed. Overall, only 15 million tonnes of the total US ECF pulp production was produced using technology comparable to the TCF processes in Scandinavia. Partly as a result of the broad spectrum of ECF processes, and chlorine gas users present in the industry, discharges of AOX may range from 0.1 to $10 \mathrm{~kg}$ per air dried tonne, and the average value cannot be easily determined. It is stated elsewhere in the literature that without oxygen delignification and an extended cooking step, ECF bleaching alone will still result in AOX loadings of up to $1 \mathrm{~kg}$ per tonne of pulp produced (Axegard et al. 1993). 
Albert (1995 a \& b; 1996) has consistently argued that chlorine chemical bleach based processes, including ECF, are unlikely to meet the terms of emerging legislative frameworks. The proposed United States Effluent Limitation Guidelines apply stringent controls to AOX, COD, Colour, BOD and TSS. The original limits proposed in 1993 would indeed be difficult to achieve with chlorine chemical based technology. This industrial sector, is however, still under assessment and the proposals are being progressively modified. The final regulations to be applied are expected to be published in early 1997. Two options appear to be favoured for application in the industry. The first $(A)$ is conventional pulping coupled with $100 \%$ chlorine dioxide bleaching while the second is oxygen delignification/ extended cooking and chlorine dioxide bleaching. These are outlined in more detail by USEPA (1995).

Hence, a substantial difference in AOX and COD discharge limitations can be expected depending upon the baseline technology. Unaccountably, despite the well documented capability of TCF processes in Scandinavia producing full brightness pulps, TCF has apparently been excluded from the options for defining a Best Available Technology (SPPT 1996), although TCF mills could qualify under incentives packages proposed. The proposed 1996 regulations differ significantly from those outlined originally in 1993. In particular, option (A) would result in AOX discharges almost three times those originally suggested in 1993.

Conversion to TCF processes has been intensively investigated and now seems established as the future system of choice for eliminating chloroorganics from the waste stream. In such processes, no chlorine chemicals are used, reliance being placed on bleaching agents such as peroxides and ozone. Research into the optimal ways of using agents such as ozone as bleach chemicals is being actively pursued (Mielisch et al. 1995) particularly with respect to carrying out bleaching at higher pulp consistencies thus reducing water usage. Other work has focussed on methods of optimising hydrogen peroxide bleaching (Axegard et al. 1996).

\section{b) Process external measures}

Process external measures largely refer to the design and construction of various types of treatment plants. The balance of employed technologies varies between region. and include activated sludge plants (Saunamaki et al. 1991), aerated lagoons (Stuthridge et al. 1991; Stuthridge \& McFarlane 1994) and anaerobic plants (Habets \& de Vegt 1991). Almemark et al. (1991) suggests that in Sweden, solids from aerated lagoon treatment tend to be discharged to water, whereas in North America, Finland and Japan, where activated sludge systems are common, sludge handling is an important component of the waste management cycle from mills. The ability of treatment systems to reduce the AOX component varies markedly, but wastewaters discharged from such plant invariably contain AOX if chlorine based chemicals are used (Stuthridge et al. 1991) while sludges may contain up to $50 \mathrm{~g}$ AOX per kg of dried material.

One aspect of the US proposed "Cluster Rules" is that it will no longer be permissible to remove contaminants from effluents and simply shift them to air, solid wastes or into products. This is of significance given the AOX residues likely to be found in sludges from various types of wastewater treatment plants as exemplified by a Swedish study (Almemark et al. 1991). Biological sludge residue in aerated treatment lagoons ranged from 0 to $5 \mathrm{~kg}$ dry solids per tonne of pulp produced. This, in turn contained between 2 and $30 \mathrm{~g}$ AOX per kilogram. In activated sludge processes, 5-25 $\mathrm{kg}$ of sludge are produced per tonne of pulp with a content of $10-25 \mathrm{~g}$ AOX per $\mathrm{kg}$. Chemical coagulation produces $4-80 \mathrm{~kg}$ of dried chemical solids per tonne of pulp and these solids contain 10-40 g AOX per kg. These figures were derived for the Scandinavian industry prior to widespread process conversions in the late 1980 's/early 1990 's, but are likely to still be highly relevant to the industry elsewhere.

The actual disposal methods used for such sludges vary from country to country. In Scandinavia, incineration in the bark boiler was often used, while in the United States, landfilling appears to be the method of choice. Almemark et al.( 1991) note that relatively little work has been carried out on the environmental impact of the various disposal methods. Nonetheless, as a general phenomenon it is known that landfill leachates can contaminate ground and surface waters. Moreover, organochlorines have been found in the flue gas of bark boilers used to incinerate sludges and chlorinated liquors and in the fly ash 
generated by these operations (Kopponen et al. 1994). These include the chlorinated dioxins and dibenzofurans. Sonnenberg and Nichols (1995) demonstrated that adding small amounts of E1 concentrate containing chlorine to black liquor increased emissions of hydrochloric acid and that PCDD and PCDF emissions increased by a factor of ten with a $1 \%$ addition of bleach plant effluent to black liquor. The spiked black liquor was combusted in both a laboratory scale plant and in a small pilot incineration plant.

Treatment of bleach plant effluents can reduce toxic effects, depending upon the bleach chemicals used and the type of treatment employed, while the move towards chlorine dioxide as a bleach chemical has also contributed (Rosemarin et al. 1990). It has become clear that the biological activity of pulp effluents may persist through conventional treatment processes. For example, a highly treated effluent in Australia was reported significantly to induce liver MFO activity in carp. Induction was poorly correlated with organochlorines extracted from the fish muscle, but appeared to be positively correlated with PCDD and PCDF levels measured in muscle (Ahokas et al. 1994).

A further problem is associated with the use of chlorine dioxide. This is the potential discharge of chlorate, a potent herbicide to which marine brown algae are particularly sensitive (Rosemarin et al. 1990; 1994). Discharges from the Swedish Monsteras mill in the early 1980s caused the brown alga Fucus vesiculosus to disappear from an area of $12 \mathrm{~km}^{2}$. While this problem appears to have largely been solved through modified effluent treatment (Landner et al. 1994), the situation outside of Scandinavia is unclear.

Finally, nutrient loadings to receiving waters are also of importance, and treatment plant is being designed to minimise emissions of nitrates and phosphates (Enell \& Haglind 1994). In areas such as Austria, such plant has operated for some years, although as in Germany, the industry is based more or less exclusively on sulphite technology (Kroiss 1994).

\section{EFFECTS OF PROCESS MODIFICATIONS ON ORGANOCHLORINE PRODUCTION}

\section{a) Non-dioxin compounds and $\mathrm{AOX}$}

There is little doubt that process internal modifications in particular have sharply reduced the quantities of organochlorines (see: Table 9) discharged from bleached kraft pulp mills. This is reflected both in studies of effluents and of recipient waters, but even where bleach sequences have been modified, if they involve chlorine based chemicals then organochlorines are discharged (Palm \& Lammi 1995). For example, in a study of two Finnish mills which eliminated elemental chlorine from the bleach sequence and substituted chlorine dioxide, sharply reduced emissions (but not elimination) of the toxicologically important chlorinated cymenes was reported (Rantio 1995). Further work has shown that levels of chlorinated cymenes and cymenenes emitted from a mill employing complete chlorine substitution were higher than from a mill where substitution was only partial (Rantio 1996a \& b). This implies that variations of within-mill systems may be highly important. In another Finnish example, levels of chlorinated PAHs in mill wastes and products were lower in birch pulp produced without elemental chlorine as compared to pine pulp bleached with elemental chlorine at the initial stage (Koistinen et al. 1994a). Koistinen et al. (1994b) also reported chlorinated fluorenes and alkyfluorenes in birch pulp bleached with chlorine dioxide, but at lower levels than in elemental chlorine bleached pine pulp.

A further Finnish study conducted analyses of levels of trichloracetic acid (TCA) in pine needles situated downwind of a pulp and paper mill using only chlorine dioxide in the bleach plant (Juuti et al. 1995). The study found a clear correlation between levels of TCA and distance from the mills with the highest levels found close to the mills. TCA is formed from the chlorohydrocarbon precursors. While the mills were clearly implicated as the source of this compound, the study was conducted only a short time after process conversion, hence the contribution of chlorine dioxide to the phenomenon is unclear. \begin{tabular}{l|l|l} 
PROCESS & Kappa & BOD $_{7}$
\end{tabular} \begin{tabular}{l|l} 
COD $_{\mathrm{Cr}}$ & Colour \\
\hline
\end{tabular} 


\begin{tabular}{|l|c|c|c|c|c|}
\hline & number & $\mathrm{kg} / \mathrm{t}$ & $\mathrm{kg} / \mathrm{t}$ & $\mathrm{kg} \mathrm{Pt} / \mathrm{t}$ & $\mathrm{kg} / \mathrm{t}$ \\
\hline \multicolumn{7}{|c|}{ BEFORE ACTIVATED SLUDGE TREATMENT: } \\
\hline Standard Kraft & $\mathbf{3 0}$ & $\mathbf{1 6}$ & $\mathbf{8 0}$ & $\mathbf{2 0 0}$ & $\mathbf{7 . 0}$ \\
\hline Extended cook & 24 & 14 & 60 & 150 & 4.8 \\
\hline Oxygen & 18 & 12 & 50 & 120 & 3.5 \\
\hline Extended $+\mathbf{O}_{2}$ & 14 & 9 & 39 & 100 & 2.8 \\
\hline \multicolumn{7}{|c|}{ AFTER ACTIVATED SLUDGE TREATMENT: } \\
\hline Standard Kraft & - & 2.4 & 45 & 180 & 3.9 \\
\hline Extended cook & - & 2.2 & 36 & 130 & 2.2 \\
\hline Oxygen & - & 2.0 & 31 & 100 & 1.9 \\
\hline Extended $+\mathbf{O}_{2}$ & - & 1.7 & 27 & 85 & 1.3 \\
\hline
\end{tabular}

TABLE 9: Effects of process internal measures designed to increase delignification of softwood kraft pulp on the quality of the bleachplant effluent. Figures before and after anaerobic treatment are shown. Kappa number can be converted to percentage residual lignin estimate by dividing the figure by six. Table reproduced from Gullichsen (1991). Bleach sequence given as $C_{D}-E_{O}-D-E-D$.

Where partial substitution of the initial chlorine charge with chlorine dioxide has been practised, untreated effluents have been found to have significant mutagenic activity and the ability to cause chronic liver injury (Metcalfe et al. 1995) although carcinogenic effects in fish were apparently absent. Mutagenic agents were also detected by Rao et al. (1994) in a mill effluent where a high degree of chlorine dioxide substitution was employed. It is, however, not clear in either case to what extent the observed effects were due to organochlorines or to nonchlorinated wood derivatives. Similarly, in studies of bleaching of eucalypt pulp $70 \%$ chlorine dioxide substitution considerably reduced but did not eliminate the production of chlorophenolics, chloroform, chloroacetones and chlorodimethylsulfones (Smith et al. 1994c).

In a US study, chlorine dioxide substitution of 60$70 \%$ (Haley et al. 1995) resulted in only a $12 \%$ decline in AOX levels although chlorinated resin acids, chlorinated phenols, chlorinated guaiacols and catechols were all reduced in the effluent by much higher percentages. At a New Zealand mill with aerated treatment lagoons and using full chlorine dioxide substitution, elevated levels of chloro-phenolic compounds were identified in the river and riverine sediments which received the effluent. Background levels of chlorophenolics were achieved approximately $20 \mathrm{~km}$ below the mill (Judd et al. 1995).

b) Chlorinated dioxins and dibenzofurans

A follow up to the US 104 Mill study (Gillespie
1996) has shown that discharges of chlorinated dioxins have been substantially reduced. Reductions are thought to be due not only bleach process changes, but the replacement of defoaming agents made from oils with a high aromatic content and contaminated with nonchlorinated dibenzo-p-dioxins and dibenzofurans as noted by Servos et al. (1994). The total relevance of the US study is open to question, however, since only the $2,3,7,8$-TCDD and TCDF isomers have been considered. Other isomers are formed in chlorine bleach operations (Campin et al. 1991; Servos et al 1994). In a study of chlorinated dioxin accumulation in fish exposed to mill effluents and employing varying degrees of chlorine dioxide substitution showed that in general the highest levels were found close to mills with lower percentage substitution and lower intensity of effluent treatment. The importance of historical inputs was not clear but could have been a confounding factor (Servos 1994).

Rappe \& Wagman (1995) analysed brownstock, ECF and TCF pulp and identified 2,3,7,8-TCDF in chlorine dioxide bleached pulp but at levels very much lower than previous reports in the literature. This is tentatively attributed to the formation of free chlorine from the chlorine dioxide. No effluents were tested in this study. Nonetheless, air sampling at a Finnish mill converted to bleach using only chlorine dioxide detected elevated levels of several chlorinated dioxins and furans, with the furans being the dominant components (Rosenberg et al. 1994). In addition, levels of $1,2,3,4,6,7,8-\mathrm{HpCDF}$, the dominant furan in the air samples, were higher in 
the blood of a group of workers at the mill than in the background population (Rosenberg et al. 1995).

Results of monitoring for chlorinated dioxins and dibenzofurans are available for the Champion Pulp Mill, Canton, North Carolina at various points in the effluent treatment process. According to Gleadow et al. (1996) this mill has two bleach lines applied to pine and hardwood pulp, using full chlorine dioxide substitution. Of the analytes determined, $2,3,4,6,7,8$-heptachlorodibenzo-p-dioxin was found in the influent to the waste treatment plant, the sludge from the treatment plant and in the leachate from the sludge. $2,3,4,6,7,8-H e x a C D F$ was present in effluent from the treatment plant. $2,3,4,6,7,8-$ HeptaCDF was detected in effluent, sludge and leachate and 2,3,7,8-TetraCDF was detected in the sludge.

\begin{tabular}{l|lcc}
\hline Mill \& Date & Bleach Sequence & $T E Q p g / l$ & $T E Q \mu g / t A D P$ \\
\hline A $[89 / 90]$ & O(C92+D8)(EO)DED & 2.8 & 0.4 \\
B [89/90] & O(D30+C70)(EPO)DED & 0.9 & 0.03 \\
C [89/90] & O(D30+C70)(EPO)DED & 0.6 & 0.03 \\
D [90] & (D80+C20)(EPO)DED & 1.0 & 0.04 \\
E [90] & (D80+C20(EPO)DED & 0.1 & $<.01$ \\
F [90] & O(D32+C68)(EPO)D(EP)D & $\mathbf{0 . 0 7}$ \\
G [90] & O(D32+C68)(EPO)D(EP)D & $\mathbf{0 . 0 3}$ \\
ECF-1 [92] & OD(EO)D(EP)D & 0.5 & N/D \\
ECF-2 [92] & OD(EO)D(EP)D & N/D & 0.02 \\
ECF-3 [93] & OD(EO)D(EP)D & 0.2 & 0.07 \\
ECF-4 [93] & OD(EO)D(EP)D & 0.9 & $<0.01$ \\
ECF-5 [93] & OD(EO)D(EP)D & 0.1 & 0.03 \\
ECF-6 [91] & OD(EPO)D(EP)D & 0.3 & 0.01 \\
ECF-7 [91] & OD(EPO)D(EP)D & 0.4 & 0.02 \\
ECF-8 [91] & OD(EPO)D)EP)D & 1.0 & 0.04 \\
ECF-9 [91] & OD(EPO)D(EP)D & 0.9 & 0.03 \\
\hline
\end{tabular}

TABLE 10: Concentrations of chlorinated dioxins found in whole mill effluent expressed as Nordic Toxic Equivalents. The bleach sequences for each plant are shown. Effluent was as follows: A: untreated, B: untreated, C: aerated lagoon, D: untreated, E: activated sludge, F: untreated, G: aerated lagoon (pilot), ECF-1: untreated, ECF-2: aerated lagoon, ECF-3: untreated, excluding rinse, ECF-4: untreated, including rinse, ECF-5: aerated lagoon, ECF-6: bleachery, ECF-7: bleachery, aerated lagoon, ECF-8: untreated, ECF-9: aerated lagoon.

On the basis of quarterly testing, the presence of these compounds was found to be variable. It is not clear whether Octa-CDD and Octa-CDF were tested for in this study. These results suggest that industrial claims that ECF alone can fully address the problem of chlorinated dioxin generation within the process may be over optimistic. In addition, a recent Swedish study investigated the concentrations of chlorinated dioxins in whole mill effluent from a number of mills using different bleach processes (Miljog3 1995). These results clearly show that chlorinated dioxins and dibenzofurans of toxicological significance are present in the wastewaters from a number of mills employing partial and complete chlorine dioxide substitution.

Hence, while chlorine dioxide substitution appears to reduce dioxin discharges, they appear to be present at detectable levels, in contradiction of the North American view that these process internal changes reduced them below detection limits (Gillespie 1996). The potential production of 2,3,7,8-TCDF is also recognised in the USEPA "Cluster Rule" proposals where an effluent limit of 24.1pg/l is suggested (SPTT 1996).

It is clear from the limited number of studies carried out on mills employing partial and full chlorine dioxide substitution, with or without oxygen delignification, that while AOX discharges may be reduced by such process internal measures, they are not eliminated. Neither is the production of toxicologically significant dioxins eliminated.

\section{CHLORINE AND CHLORINE DIOXIDE LINKAGE}

It has been suggested by Rappe and Wagemann 
(1995) that the explanation for chlorinated dioxins found in brownstock was due to the presence of elemental chlorine in the bleaching gas. Reeve $e t$ al. (1995) established that decreasing the pulp consistency, increasing the $\mathrm{pH}$ or reducing the chloride ion at low $\mathrm{pH}$ all tended to reduce $\mathrm{AOX}$ discharged with the effluent. The Swedish study

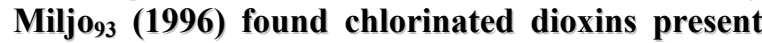
in ECF effluents. These findings suggest that ECF is an incorrect term due to the inevitable presence of elemental chlorine. Hence ECF processes cannot correctly be described as chlorine free under existing definitions. For example, The Confederation of European Paper Industries (CEPI 1992) has published the following definition of ECF:

ECF (Elemental Chlorine Free) refers to a pulp bleaching process which does not use chlorine gas.

Elemental chlorine can be present in chlorine dioxide through two routes. Production of chlorine dioxide is accompanied by the coproduction of elemental chlorine. All commercial processes are based upon the reaction of a reducing agent with sodium chlorate. This may be hydrogen chloride, sodium chloride, sulphur dioxide or methanol. The sulphur dioxide process (Mathieson process) produces less elemental chlorine than other reducing agents (Clapper 1978; McDonough 1992). A proportion of the elemental chlorine can be absorbed in the scrubbing tower used to prepare the bleaching solution. In systems using chloride as the reducing agent, the chlorine dioxide may have up to $15 \%$ by weight of chlorine (Rapson \& Strumila 1979). Where a sulphur dioxide based system is used, the produced chlorine dioxide can contain between 1 and 5\% elemental chlorine (Kaczur \& Caulfield 1994).

Fredette, (1996) notes that where sodium chloride is used in the $\mathrm{R} 2$ process, it produces around $0.6 \mathrm{t}$ of chlorine per tonne of chlorine dioxide. Approximately 1g/l appears in the chlorine dioxide solution while the balance is used to manufacture hypochlorite. Virtually all R2 units were sold in the Southern United States. Subsequent $R$ series and SVP series plants were designed to reduce waste acid output, but increased levels of $2 \mathrm{~g} / \mathrm{l}$ of chlorine were present in the chlorine dioxide solution. Eventually, hydrochloric acid based systems were developed. This could be made from the by produced chlorine. Even in plants using methanol, chlorine is not eliminated due to the need for chloride ion to be present in the reaction mixture. In the $R 8$ process $0.1 \mathrm{~g} / \mathrm{l}$ of chlorine are present in a solution of $10 \mathrm{~g} / \mathrm{l}$ of chlorine dioxide. Hydrogen peroxide processes which can eliminate the chlorine byproduction entirely are limited by the high cost of using peroxide in these processes. CEFIC (1993) also recognise the by-production of chlorine in chlorine dioxide generation. Reeve (1996b) notes that with the R2 \& R3/SVP producing a $10 \mathrm{~g} / \mathrm{l}$ chlorine dioxide solution, $10 \%$ of the oxidising equivalents are provided by chlorine.

Even if this problem of chlorine by-production is solved, free chlorine is also generated during bleaching with chlorine dioxide as noted by Rapson and Strumila (1979) and Reeve et al. (1995) Hypochlorous acid is generated as an intermediate. Chlorine dioxide reacts with the pulp to produce bleached pulp and chlorous acid. A pH dependent equilibrium then becomes established between the chlorous acid, chlorite ion and hydrogen ion. The concentration of chlorous acid becomes lower with increase in $\mathrm{pH}$ value. Chlorous acid is highly reactive towards lignin and in the course of the reaction is reduced to hypochlorous acid. In the presence of chloride ion, the hypochlorous acid enters into another $\mathrm{pH}$ dependent equilibrium with free chlorine being evolved. This free chlorine is available to produce chlorinated organic compounds measured as AOX. Hence, "elemental chlorine free", where this means "molecular chlorine free" is not true of any bleach sequence involving chlorine dioxide. Gaseous chlorine is inevitably evolved either in the production of chlorine dioxide or in the pulp mixture to which it is applied. Ultimately, therefore, it appears that only those commercial processes entirely free of chlorine chemicals as bleach agents merit the term of elemental chlorine free.

\section{BIOLOGICAL IMPACTS OF MILL DISCHARGES-RECENT RESEARCH}

Recent research work has established that even with reduced AOX discharges, mill effluents can exert significant impacts upon the receiving environment. Some follow-up work to the original Swedish studies (Sodergren 1989; 1993) have been conducted upon receiving environments for 
bleached kraft pulp mill effluents in order to gauge the effects of conversion from elemental chlorine to other bleaching agents. These have generally shown that following process changes, some recovery of the environment takes place but this is not complete. Sandstrom (1994) reported on abnormalities in fish populations exposed to mill effluent. Following the introduction of chlorine dioxide at the Norrsundet Mill in Sweden, some abnormalities were no longer recorded. Nonetheless, the abundance of adult perch was low and high levels of larval mortality and low embryo quality were recorded in the area within $1-2 \mathrm{~km}$ of the mill.

Kankaanpaa et al. (1995) investigated the effect of effluent from a mill using $\mathbf{1 0 0 \%}$ chlorine dioxide in the bleach process upon the behaviour of an ecologically important Baltic Sea amphipod. The effluent contained $8.3 \mathrm{mg} / \mathrm{l}$ AOX. Negative impacts were observed upon swimming activity in the test animals following exposure to the effluent at AOX levels diluted to between 150 and 400 micrograms per litre. Kovacs et al. (1995) found that secondarily treated effluent from a plant employing $45 \%$ chlorine substitution for elemental chlorine suppressed reproduction in test fish.

Effluent from a mill using $\mathbf{7 0} \%$ chlorine dioxide substitution caused induction of liver mixed function oxidase enzymes, an index of pollution stress, in largemouth bass. Effluent concentrations of $8 \%$ and $4 \%$ effluent were used in artificial streams. Even after oxygen delignification was installed and full substitution of the chlorine by chlorine dioxide, enzyme induction resulted in fish exposed to $4 \%$ and $12 \%$ effluent in artificial streams (Bankey et al. 1995). Similar findings were made for trout exposed to effluent from a mill employing increased chlorine dioxide substitution (Haley et al. 1995) and a positive dose response relationship was observed.

Suppression of immune parameters was recorded in roach exposed to effluent from a mill employing 25\% chlorine substitution in Finland (Jokinen et al. 1995). Further subtle effects were identified in a comparative Canadian study which revealed that fish exposed to bleached kraft mill effluent showed reduced investment in reproduction, reduced gonad size and reduced fecundity when compared to fish taken from an uncontaminated site (Gagnon et al. 1995), although the precise bleach sequence was not given in the study. More intriguingly, the short term growth of mayfly larvae was stimulated by exposure to effluent from a bleached kraft mill in Canada (Lowell et al. 1995) leading the authors to speculate that chemicals acting upon the insect endocrine system could be responsible. An apparent stimulation of fish growth in the short term is also apparent from the work of Haley et al. (1995).

Comparison of low level, long term effluent toxicity between mills using a variety of bleach processes has shown that effluents derived from elemental chlorine bleaching are indeed the most toxic. In a study of structure of artificial ecosystems exposed to mill effluents, the least structural disturbance was recorded in the system exposed to bleachery effluent from a fluff pulp mill using an OPD bleach sequence. Intermediate disturbances were reported from effluent exposures where partial chlorine dioxide substitution was used in the initial bleaching step after an oxygen delignification step, for example, O(C85+D15)(EO)DED. The most serious disturbances were reported in systems exposed to effluent derived from a CEHDED sequence (Tana et al. 1994).

These observations have been generally confirmed in the industry (Axegard et al. 1993) where lowered chlorine charge has resulted in reduced impacts. In mills using chlorine dioxide, AOX levels have been reduced further. There appears to be no correlation between AOX discharge levels and environmental impact, a phenomenon noted also by Tana et al. (1994) in their studies of specific responses of fish. In addition, other observations (Barker et al. 1994) have documented a variety of lesions in fish sampled adjacent to a mill using sodium hydrosulphite as a bleaching agent, with no chlorine chemicals in use.

Grahn \& Grotell (1995) reported that some environmental impacts were significantly reduced when totally chlorine free (TCF) bleach processes were used in comparison to ECF processes using chlorine dioxide, confirming earlier work (Lovblad \& Malmstrom 1994). Kovacs et al. (1995) reported that the overall toxicity of effluents tested in a bioassay was untreated ECF $>$ untreated TCF $>$ secondary treated ECF $>$ secondary treated TCF. In previously published studies noted by Kovacs et al. (1995), the differences between TCF and ECF derived effluents were less marked. They note that 
generalisations regarding a particular process and the subsequent effects upon the mill discharge are difficult to make.

One particular problem in making comparisons stems from the wide range of potential ECF processes discussed above. Comparisons are strictly only valid when comparing low kappa ECF after chlorate ion removal with TCF effluents. A further complication in comparing between studies is the fact in some of these mill effluents were synthesised in the laboratory rather than taken from real mill operations. These were subjected to various non-standard treatments and were, therefore, not representative of the products of the different and complex reactions occurring within the mill. This fundamental criticism can be levelled at, for example, the work of O'Connor et al. (1993) which is widely cited as evidence of ECF effluents being less toxic than TCF effluents.

One study found a high acute toxicity of untreated TCF effluent and this was identified as due to residual hydrogen peroxide. The toxicity could be removed completely by biological treatment. The treatability of the effluents produced by TCF processes in comparison to wastewaters from chlorine gas and chlorine dioxide bleaching of softwoods was investigated in the same study. Activated sludge treatment reduced the COD of TCF effluents by $55-65 \%$ as against $35-45 \%$ for wastewaters containing chlorine compounds. Similarly, chemical flocculation produced positive $85 \%$ removal of COD from TCF wastewaters (Saunamaki 1995).

One key concern in relation to TCF mills is the use of chelating agents to control metal build up in the processes which could affect peroxide and oxygen bleaching. The degree to which these could affect metal mobilisation in the wider environment is not clear but could be significant. The concentrations of metals present in TCF wastewaters have been found to be higher than in other bleachery effluents, probably due to the EDTA content. The EDTA is also responsible for raised nitrogen emissions and, in common with DTPA, does not readily degrade under biological treatment.

Overall, such studies demonstrated that while environmental improvements could be achieved by process changes and that the elimination of chlorine based chemicals was a key factor in such improvements, effluents from all processes were toxic to some degree. Indeed, these and similar findings led to increasing suspicions that chemicals other than the AOX components present in pulp and paper effluents were at least partially responsible for observed changes in fish populations. It has been known for some time that acute effects of pulp effluents were attributable to resin and fatty acids released from the processed wood. These components present in the effluent of a thermomechanical pulp mill were found to be lethal to trout after 2-4 weeks exposure at a two hundred fold dilution (Johnsen et al. 1995). Analyses of resin acids in the fish showed a positive dose-response correlation.

Resin acid contamination in sediments was found to correlate with significant behavioural modification in benthic invertebrate species (Hickey \& Martin (1995). The resin and fatty acids from wood, however, are considered to be largely removed by biological treatment (see: Owens 1991) while Zender et al. reported a $96 \%$ removal of these components by secondary treatment in a New Zealand plant. The greatest mass flow was from the foul condensate stream and extraction bleaching stages.

An extensive study of Canadian mills using a variety of pulp production processes revealed that physiological changes in fish exposed to effluent were associated with significant effects upon reproductive development. These effects were also associated with changes in liver mixed function oxidase activity. Moreover, the effects were recorded at very low effluent concentrations and the causative agent or agents were not removed during normal secondary treatment. Significantly the observed effects did not correlate with AOX levels in the effluent or levels of dioxins and furans (Carey et al. 1992). These studies have subsequently been reported in considerable detail. The precise relevance of MFO induction measured as ethoxyresorufin-O-deethylase (EROD) is open to question in view of recent research showing that temperature can strongly influence the induction of this enzyme and the cytochrome P4501A system in marine fish species as well as exposure to xenobiotic chemicals. (see: Eggens et al. 1995; Sleiderink et al. 1995 a, b \& c). Even so, MFO enzyme activity was induced in fish living in the recipients of most mill wastewaters examined.

The mills studied are described, together with the receiving water characteristics, by Robinson et al. 
(1994). All discharged in excess of 40,000 cubic metres of effluent per day and included bleached kraft producers and sulphite/mechanical pulp mills. Induction of liver MFO enzymes and depression of plasma sex steroid levels were identified downstream of several mills including some without chlorine bleaching and with advanced secondary treatment (Munkittrick et al. 1994). Other responses such as reduced gonad size and enlarged livers were also found in fish near mills using chlorine and mills using no chlorine chemicals. The effects in feral populations could not be predicted from the results of laboratory toxicity tests on a variety of species. As noted above, there was no apparent correlation with PCDD/PCDF levels and changes in physiological parameters or the biomarkers used with the exception of EROD induction. PCDD and PCDF levels were, however, higher near mills using elemental chlorine than those using other bleach agents or no bleaching at all (Servos et al. 1994). 2,3,7,8-TCCD toxic equivalence levels were strongly and negatively correlated with testosterone levels in fish of both sexes (Heuvel et al. 1994).

\section{ENDOCRINE DISRUPTION \& PULP AND PAPER MILLS}

The findings from the Canadian research programme coupled with observations made in the Baltic sector focussed attention on natural plant components, particularly those capable of interfering with the endocrine systems responsible for hormone synthesis and metabolism. Landner et al. (1994) suggested that natural sterols present in the wood such as $\alpha$ - and $\beta$-sitosterol could be a factor since administration of these compounds to fish induced similar responses to pulp and paper mill effluent exposure. This theme was also taken up by Tana et al. (1994) who noted that a proportion of these chemicals extracted from wood would not be cycled through the recovery process, but would be passed to the bleach and effluent treatment plants.

The current situation is analogous to that prevailing after regulatory initiatives to control BOD and COD discharges in the 1980's and before. Removal of BOD from effluents led to improvement in recipient quality, but allowed the identification of effects due to other agents present in discharges, specifically organochlorines, which had previously been obscured. Progressive reduction of organochlorine loading similarly, has allowed the identification of yet further impacts due to other chemicals. (see: eg. Owens 1991).

In fact, laboratory studies as early as 1941 had established that it was possible to masculinise mosquito-fish using artificial hormones. It was reported in 1991 that androstenedione, androstanol and spironolactone could achieve the same result. In 1978 it had been reported that phytosterols present in tall oils recovered from wood could be converted by microbes to steroids. Tall oil consists of $\mathbf{2 5 - 2 5 \%}$ phytosterols. Hence, the total phytosterol production by this route alone in the US was estimated at 20,000 tons. (see: Davis \& Bortone 1992). These same changes can be produced by exposing fish to kraft mill effluent, although the authors do not specify whether this was derived from a chlorine chemical bleach line.

As a result, there are now two distinct elements to the debate about environmental protection from pulp and paper operations. The Canadian findings have prompted the industry into large scale questioning of the utility of reducing AOX emissions any further. For example, Myreen (1994) cites the opinion of scientists in the Nordic countries and Canada that reductions of organochlorines below $1.5 \mathrm{~kg}$ AOX/ADT pulp represents an inefficient use of resources. The precise basis for this view is obscure.

Malinen et al. (1994) advance a similar viewpoint in their analysis of the future of the industry in Finland. The views subsequently diverge markedly. While Malinen et al. (1994) propose the development of treatment plant to address the residual problems, Myreen (1994) considers that total effluent free (TEF) production is now accepted by the industry as the decisive step towards environmentally friendly pulp and paper production. In light of the Canadian findings and the realisation that all pulp mills can emit endocrine disruptive chemicals on a large scale, closure of the mill circuits may be seen as an environmental imperative for the industry, a theme taken up and discussed by Albert (1995b). In most geographical areas there appear to be clear present and likely future environmental, market and fiscal incentives to move towards TEF production. 


\section{TOTALLY EFFLUENT FREE PROCESSES- CLOSING THE BLEACH CIRCUITS}

Currently, zero effluent operation appears to be restricted to plants producing bleached chemical thermal mechanical pulp and non-chlorine bleaching agents (Edde, 1994). As noted earlier, the bleach plant is the major source of contaminated effluent in a kraft pulp mill. Hence closure of these circuits is an essential prerequisite for producing a zero-effluent kraft mill. Myreen (1994) points out that this requires the simultaneous resolution of a number of problems. These include water balance, chemicals balance, corrosion, precipitation of salts and removal of non-product substances. Development work is being directed at closing both ECF and TCF bleach circuits. Closure of the bleach plant circuits implies a large scale increase in the levels of organic and inorganic matter in the process liquors and filtrates which need to be accommodated (Krotscheck et al. 1995).

Albert (1995a) provides a cost breakdown for a reference kraft mill in relation to an effluent free plant based on ozone and peroxide bleaching which has considerable capital and running cost advantages. This allows for the re-use of all process waters in the brownstock circuits and the chemical recovery circuits. In addition to significant chemical cost savings, there is no need for capital investment in primary and secondary effluent treatment plant. A closed cycle TCF plant does not require substantially different recovery boiler design (Gleadow et al. 1995) but may involve the treatment of purge lines to control potassium and chloride levels entering with the mill furnish. Moreover, a recent analysis (Laxen \& Henricson 1996) has shown that TCF processes are economical in terms of the energy used in the generation of ozone.

Due to lower chloride levels in the process liquors, TCF processes undoubtedly have an advantage over ECF processes since the chloride introduced is from the mill furnish alone. ECF bleach plant effluents contain high levels of chloride ion from the bleaching reaction in addition to non-process sources. A major problem is corrosion as noted by Edde (1994) due to the presence of corrosive chloride salts. D stage filtrates are also highly acidic, exacerbating corrosion problems (Manolescu et al. 1995). If ECF circuits are to be closed therefore, some means of dealing with both the chlorinated organics and inorganic chlorides is required. Most proposed systems include an incineration step (Myreen 1994; Manolescu et al. 1995). Incineration has been suggested both for evaporates and filtrates from the bleach line and for organochlorine containing sludges from wastewater treatment plant. Other suggested systems such as flocculation followed by electrodialysis are at an extremely early stage of development (Johansson et al. 1995).

The incineration of organochlorine wastes has been shown to produce and emit a wide range of organochlorines of toxicological significance. This is due to the reaction of organic fragments with hydrogen chloride and free chlorine gas in the process, particularly in the gas phase. These compounds include the chlorinated dibenzo-pdioxins and dibenzofurans together with chlorinated phenols and benzenes (see: eg Cains \& Dyke 1994; Wienecke et al. 1995; Heeb et al. 1995; Jay \& Stieglitz 1995).

Combustion of air dried concentrates from ECF processes has been shown to evolve both hydrogen chloride and free chlorine in pilot studies (Manolescu et al. 1995). Sharply elevated levels of PCDDs and PCDFs were formed in a laboratory scale combustion furnace by incinerating black liquor with $1 \%$ chlorine bleach effluent added (Sonneberg \& Nichols 1995). PCDDS and PCDFs were isolated from a number of flyash samples derived from the experimental combustion of bleached kraft mill primary and biological sludge mixed with bark (Kopponen et al. 1994). Similar emission considerations apply to proposals to route ECF waste streams through the recovery boiler, which in addition will require boiler design to be adapted to tolerate higher chloride levels (Gleadow et al. 1995). The incineration of chlorinated bleach plant wastes is likely to prove a significant barrier to the closure of ECF bleach lines. This is due both to the technical difficulties involved and a growing lack of public acceptance of incineration processes generally. In addition, the inevitable presence of organochlorines in the sludges and other process wastes is likely to fail the test of the USEPA "Cluster Rule" (Albert 1995b) under the original 1993 proposals.

Precise cost estimates for construction and operation of a new zero effluent bleached kraft mill using ozone as compared to a standard mill using chlorine dioxide have been generated by Albert (1995a). A TEF mill constructed on this 
basis would incur capital costs of $\$ 585$ million as against \$625 million for an ECF plant. Operating costs for the TEF mill would be $\$ 58$ per ADT as compared to \$93 per ADT for a standard mill. In the case of converting an existing mill, the distinction is less clear, but the balance still favours TCF processes. To close an existing ECF mill operating on chlorine dioxide could incur costs of $\$ 98$ million with incremental costs of $\$ 3$ per ADT. To convert to TCF would cost $\$ 96$ million with incremental costs of $\mathbf{- \$ 2}$ per ADT (Ricketts 1994). These estimates are recognised to be variable and site sensitive, but nonetheless favour TCF processes. Significantly, the largest cost element associated with conversion of an ECF mill is combustion plant for acid filtrate concentration and incineration.

Acknowledgements:

Thanks are due to Lee Godfree and Jeff Jones for preparation of the figures.

\section{REFERENCES}

AET (1996) Trends in World Bleached Chemical Pulp Production 1990-1996. Publ. Alliance for Environmental Technology, March 1996, 4 pp

Ahokas, J.T., Holdway, D.A., Brennan, S.E., Goudey, R.W. \& Bibrowski, H.B. (1994) MFO activity in carp (Cyprinus carpio) exposed to treated pulp and paper mill effluent in Lake Coleman, Victoria, Australia, in relation to AOX, EOX and muscle PCDD/PCDF. Environmental Toxicology and Chemistry 13: 41-50

Albert, R.J. (1994) Worldwide Survey: State of the Art TCF bleaching. Proc. 1994 International Non-chlorine Bleaching Conference March 1994 Amelia Island, Florida 25pp \& Appendices

Albert, R.J. (1995a) Technical and Economic Feasibility of the Closed Cycle Bleached Kraft Pulp Mill. Proc. 1995 International NonChlorine Bleaching Conference, March 5-9, 1995, Amelia Island Florida, 23pp \& Appendices 
Albert, R.J. (1995b) Worldwide status of effluent free technology for bleached kraft pulp production. Proc. 1995 International NonChlorine Bleaching Conference, March 5-9, 1995, Amelia Island Florida 37pp \& Appendices

Albert, R.J. (1996) Current status of TEF bleached kraft pulp mills and future trends. Proc. 1996 International Non-Chlorine Bleaching Conference, Orlando Fla. March 24-28 1996

Almemark, M., Finnveden, G. \& Frostell, B. (1991) Treatment technologies for organochlorine-containing sludges and concentrations from external treatment of pulp and paper wastewaters. Water Science \& Technology, 24 (3-4): 319-329

Axegard, P., Dahlman, O., Haglind, I., Jacobson, B., Morck, R. \& Stromberg, L. (1993) Pulp Bleaching and the Environment- The Situation, 1993. Nordic Pulp and Paper Research Journal 8 (4): $365-378$

Axegard, P., Bergnor, E., Elk, M. \& Ekholm, U. (1996) Bleaching of softwood kraft pulps with $\mathrm{H}_{2} \mathrm{O}_{2}, \mathrm{O}_{3}$ and ClO . Tappi Journal, 79 (1): 113-119

Bankey, L.A., Van Veld, P.A., Borton, D.L., LaFleur, L. \& Stegeman, J.J. (1995). Responses of cytochrome P4501A1 in freshwater fish exposed to bleached kraft mill effluent in experimental stream channels. Canadian Journal of Fisheries and Aquatic Science 52: 439-447

Barker, D.E., Kahn, R.A., Lee, E.M., Hooper, R.G. \& Ryan, K. (1994) Anomalies in Sculpins (Myxocephalus spp.) sampled near a pulp and paper mill. Archives of Environmental Contamination and Toxicology 26: 491-496

Bergman, A., Pilotti, A. \& Renberg, L. (1994) Potential Formation of Chlorinated By-products in Industrial Processes. Publ. Swedish National Chemicals Inspectorate 13pp \& Appendices

Botha, N. (1995) The outlook for the world chloralkali industry. Chemistry and Industry, 16 October, 1995

Burt, L. (1987) Pulp and paper technology changes will boost chemical needs. Process Ind. Canada (October-November 1987) 23-26

Buser, H.-R., Kjeller, L.-O., Swanson, S.E. \& Rappe, C. (1989) Methyl- polymethyl- and alkylpolychlorodibenzofurans identified in pulp mill sludge and effluents. Environmental Science \& Technology 23 (9): 1130-1137

Bystrom, S., \& Lonnstedt, L. (1995) Waste paper usage and fiber flow in Western Europe. Resources Conservation \& Reycling 15: 111121

Cains, P.W. \& Dyke, P. (1994) Chlorinated dibenzodioxin and dibenzofuran emissions from waste combustion plants in the UK. Chemosphere, 28 (12): 2101-2119

Campin, D.N., Buckland, S.J., Hannah, D.J. \& Taucher, J.A. (1991). The identification of dioxin sources in an integrated wood processing facility. Water Science and Technology. 24 (3/4): 65-74

Carey, J.H., Hodson, P.V., Munkittrick, K.R. \& Servos, M.R. (1992) Recent Canadian studies on the physiological effects of pulp mill effluent on fish. Publ. Environment Canada, Dept. of Fisheries and Oceans Special Report, Burlington Ontario 20pp

CEFIC (1993) Chlorine Dioxide in Pulp Bleaching, Publ. CEFIC Chlorate Sector Group, Brussels, 1993

CGB (1987). Committee for the Gulf of Bothnia. Water pollution problems of pulp and paper industries in Finland and Sweden. Report No:3348 publ. National Swedish Environmental Protection Board pp 122 \& Appendices

Clapper, T.W. (1978) Chlorine oxygen acids and salts $\left(\mathrm{HClO}_{3}\right)$ In: Volume 5, Grayson. M. [Ed]. Kirk-Othmer Encyclopedia of Chemical Technology. 3rd Edition, Publ. John Wiley \& Sons, New York pp633-645

Davis, W.P. \& Bortone, S.A. (1992) Effects of kraft mill effluent on the sexuality of fishes: An environmental early warning. In: Colborn, T. \& Clement C. [Eds]. Chemically-Induced Alterations in Sexual and Functional Development: The Wildlife-Human Connection. Volume XXI Advances in Modern Environmental Toxicology, Publ. Princeton Scientific Publishing Company, New Jersey pp113-127

Downs, T. (1989) Paper industry on right track with latest effluent control strategies. Pulp \& Paper, September 1989, p74

Ebeling, G. (1931). Recent results of the chemical investigation of the effect of wastewaters from cellulose plants on fish. Vom Wasser 5: 192-200

Edde, H. (1994) Techniques for closing the water circuits in the pulp and paper industry. Water Science and Technology 29 (5-6): 11-18

Eggens, M., Bergman, A., Vethaak, D., van der Weiden, M., Celander, M. \& Boon, J.P. (1995) Cytochrome P4501A indices as biomarkers of contaminant exposure: results of a field study with plaice (Pleuronectes platessa) and flounder (Platichthys flesus) from the Southern North Sea, Aquatic Toxicology 32: 211-225

Enell, M. \& Haglind, I. (1994) Nitrogen, phosphorus amd metal loads from Swedish pulp and paper industry on the Gulf of Bothnia- 
Quantities and shares of total load. Water Science \& Technology 29 (5-6): 49-59

Farr, J.P., Smith, W.L. \& Steichen, D.S. (1992) Bleaching Agents (Survey) In: Volume 4. Grayson, M. (Ed). Kirk-Othmer Encyclopedia of Chemical Technology. 4th Edition. Publ. John Wiley \& Sons, New York. pp271-300

Folke, J. (1991) Regulatory requirements for pulp and paper mill effluent control: Scientific basis and consequences. Water Science and Technology 24 (3/4) 19-31

Forlin, L., Andersson, T., Balk, L. \& Larsson, A. (1995) Biochemical and physiological effects in fish exposed to bleached kraft mill effluents. Ecotoxicology and Environmental Safety 30: 164-170

Fredette, , M.C. (1996) Bleaching Chemicals: Chlorine Dioxide Section 2, Chapter 2 In: B Dence, C.W. \& Reeve, D.W. [Eds] Pulp Bleaching: Principles and Practice. Tappi Press, Atlanta pp59-69

Gagnon, M.M., Bussieres, D., Dodson, J.J. \& Hodson, P.V. (1995). White sucker (Catostomus commersoni) growth and sexual maturation in pulp mill contaminated and reference rivers. Environmental Toxicology and Chemistry 14 (2): 317-327

Gifford, J.S. \& McFarlane, P.N. (1991) The development of environmental control legislation and effluent standards for Australasian wood processing industries. Water Science and Technology 24 (3-4): 37-44

Gillespie, W.J. (1996) A summary of data reflective of US pulp and paper industry progress in reducing the TCDD and TCDF content of effluents, pulps and wastewater treatment sludges. Chemosphere 32 (1): 65-71

Gleadow, P., Hastings, C., Brynin, J., Johnson, T. \& Warnqvist, U (1995). Closed Cycle Kraft: ECF v. TCF. Proc. 1995 International Non-Chlorine Bleaching Conference, Amelia Island. Fla. March 5-9, 1995

Gleadow, P.L., Vice, K., Johnson, A.P., Sorenson, D.R. \& Hastings, C.R. (1996). Mill applications of closed cycle technology Proc. 1996 International Non-Chlorine Bleaching Conference, Orlando Fla. March 24-28, 1996

Grahn, O. \& Grotell, C. (1995) Effects in model ecosystems of bleach plant and whole mill effluents from production of TCF- and ECFbleached softwood kraft pulp at the Sodra Cell AB mill Varo Bruk. Publ. Environmental Research and Consulting, MFG Environmental Research Group, Fryksta, Sweden, 16pp

Gullichsen, J. (1991) Process internal measures to reduce pulp mill pollution load. Water Science and Technology 24 (3-4): 45-53

Gunnarsson, U. (1995) AET and "allied" friend of ECF and an enemy of TCF. Responze from Sodra-Cell, March 1995 p5

Habets, L.H.A. \& Vegt, A.L. de (1991) Anaerobic treatment of bleached TMP and CTMP effluent in the BIOPAQ UASB system. Water Science and Technology 24 (3-4): 331-345

Harriman Chemsult (1989) Bleaching of Woodpulp in the 1990's in Western Europe. Publ. Harriman Chemsult Ltd, London (Mimeo Report)

Haley, R.K., Hall, T.J. \& Bousquet, T.M. (1995) Effects of biologically treated bleached kraft mill effluent before and after mill conversion to increased chlorine dioxide substitution: Results of an experimental streams study. Environmental Toxicology and Chemistry 14 (2): 287-298

Hassi, H. (1993) Bleaching development. Paper, June 1993, p38-39

Heeb, N.V., Dolezal, I.S., Buhrer, T., Mattrel, P., \& Wolfensberger, M. (1995) Distribution of halogenated phenols including mixed brominated and chlorinated phenols in municipal waste incinerators. Chemosphere, 31 (4): 3033-3042

Heuvel, van den, M.R., Munkittrick, K.R., van der Kraak, G.J., McMaster, M.E., Porrt, C.B., Servos, M.R. \& Dixon, D.G. (1994) Survey of receiving-water environmental impacts associated with discharges from pulp mills. 4. Bioassay derived 2,3,7,8-tetrachlorodibenzo-pdioxin toxic equivalent concentration in white sucker (Catostomus commersoni) in relation to biochemical indicators of impact. Environmental Toxicology and Chemistry 13 (7): 1117-1126

Hickey, C.W. \& Martin, M.L. (1995) Relative sensitivity of five benthic invertebrate species to reference toxicants and resin acid contaminated sediments. Environmental Toxicology and Chemistry 14 (8): 1401-1409

Hocking, J. (1991) Regulation of discharge of organochlorines from pulp mills in Canada. Environ. Manage. 15 (2): 195-204

Hytotylainen, J. (1994) Chemical degradation products of lignin and humic substances. Part II: Synthesis, structure verification and liquid chromatographic separation of chlorinated protocatechualdehydes (3,4- dihydroxybenzaldehydes), 5-hydroxyvanillins (3,4dihydroxy-5-methoxy-benzaldehydes and gallaldehydes (3,4,5-trihydroxybenzaldehydes). Chemosphere 28 (9): 1641-1656

Jay, K. \& Stieglitz, L. (1995) Identification and quantification of volatile organic components in emissions of waste incineration plants Chemosphere, 30 (7): 1249-1260 
Jokinen, E.I., Aaltonen, T.M. \& Valtonen, E.T. (1995) Subchronic effects of pulp and paper mill effluents on the immunoglobulin synthesis of roach Rutilus rutilus. Ecotoxicology and Environmental Safety 32: 219-225

Johansson, N.G., Clark, F.M. \& Fletcher, D.E. (1995) New technology developments for the closed cycle bleach plant. Proc. 1995 International Non-Chlorine Bleaching Conference, March 5-9, 1995, Amelia Island Florida.

Johnsen, K., Mattsson, K., Tana, J., Stuthridge, T.R., Hemming, J. \& Lehtinen, K.-J (1995) Uptake and elimination of resin acids and physiological responses in rainbow trout exposed to total mill effluent from an integrated newsprint mill. Environmental Toxicology and Chemistry 14 (9): 1561-1568

Judd, M.C., Stuthridge, T.R., Tavendale, M.H., McFarlane, P.N., Mackie, K.L., Buckland, S.J., Randall, C.J., Hickey, C.W., Roper, D.S., Anderson, S.M. \& Steward, D. (1995) Bleached kraft mill sourced organic chemicals in sediments from New Zealand rivers. Part I: Waikato River. Chemosphere, 30 (9): 1751-1765

Juuti, S., Norokorpi, Y. \& Ruuskanen, J. (1995) Trichloroacetic acid (TCA) in pine needles caused by atmospheric emissions of kraft pulp mills. Chemosphere 30 (3): 439-448

Kaczur, J.J. \& Caulfield, D.W. (1994) Chlorine Oxygen Acids and Salts $\left(\mathrm{ClO}_{2}\right.$, $\left.\mathrm{HClO}_{2}\right)$. In: Volume 5: Grayson, M. (Ed.) Kirk-Othmer Encyclopedia of Chemical Technology. John Wiley \& Sons, New York, pp968-977

Kallqvist, T., Carlberg, G.E. \& Kringstadt, A. (1989) Ecotoxicological characterisation of industrial wastewater- Sulfite pulp mill with bleaching. Ecotoxicology \& Environmental Safety 18: 321-336

Kankaanpaa, H., Lauren, M., Mattson, M. \& Lindstrom, M. (1995) Effects of bleached kraft mill effluents on the swimming activity of Monoporeia affinis (Crustacea, Amphipoda) Lindstrom. Chemosphere 31 (11/12): 4455-4473

Kerski, A. (1995) Pulp, Paper and Power: How an industry reshapes its social environment. Ecologist 25 (4): 142-148

Koistinen, J., Nevalainen, T., Tarhanen, J. (1992) Identification and level estimation of aromatic co-eluates of polychlorinated dibenzo-pdioxins and dibenzofurans in pulp mill products and wastes. Environmental Science and Technology 26: 2499-2507

Koistinen, J., Paasivirta, J., Nevalainen, T. \& Lahtipera, M. (1994a) Chlorophenanthrenes, alkylchlorophenanthrenes and alkylchloronaphthalenesin kraft mill products and discharges. Chemosphere 28 (7): 1261-1277

Koistinen, J., Paasivirta, J., Nevalainen, T. \& Lahtipera, M. (1994b) Chlorinated fluorenes and alkylfluorenes in bleached kraft pulp and pulp mill discharges. Chemosphere 28 (12): 2139-2150

Kopponen, P., Valttila, O., Talka, E., Torronen, R., Tarhanen, J., Ruuskanen, J., Karenlampi, S. (1994) Chemical and biological 2,3,7,8tetrachlorodibenzo-p-dioxin equivalents in fly ash from combustion of bleached kraft pulp mill sludge. Environmental Toxicology and Chemistry 13: 143-148

Kringstadt, K.P. \& Lindstrom K. (1984) Spent liquors from pulp bleaching. Environmental Science and Technology 18 (8): 236A-248A

Kovacs, T.G., Gibbons, J.S., Tremblay, L.A., O'Connor, B.I., Martel, P.H. \& Voss, R.H. (1995) The effects of a secondary treated bleached kraft mill effluent on aquatic organisms as assessed by short term and long term laboratory tests. Ecotoxicology and Environmental Safety 31: 7-22

Kovacs, T.G., Tana, J., Lehtinen, K.-J. \& Sangfars, O. (1995) A comparison of the environmental quality of elemental chlorine free (ECF) and totally chlorine free (TCF) Hardwood bleach plant effluents. Proc. 1995 International Non-Chlorine Bleaching Conference, March 59, 1995, Amelia Island Florida, 23pp

Kroiss, H. (1994) Water protection in the pulp and paper industry: Austrian and Central European situation. Water Science and Technology 29 (5-6): 33-48

Landner, L., Grahn, O., Hardig, J., Lehtinen, K.-J., Monfelt, C. \& Tana J. (1994) A field study of environmental impacts at a bleached kraft pulp mill site on the Baltic Sea coast. Ecotoxicology and Environmental Safety 27: 128-157

Laxen, T. \& Henricson, K. (1996) Energy efficiency in ECF and TCF bleaching. Pulp \& Paper, Canada 97 (1): 58-61

Lee, H.-B., Hong-You, R.L. \& Fowlie, P.J.A. (1989) Chemical derivatization analysis of phenols. Part IV. Determination of chlorinated phenolics in pulp and paper effluents. Assoc. Off. Analytical Chemistry. 72 (6): 979-984

Lindesjoo, E. (1992) Fish Diseases and Pulp Mill Effluents. Acta Univ. Ups. Comprehensive Summaries of Uppsala Dissertations from the Faculty of Science 330. Publ. University of Uppsala,, Sweden, 39pp

Loon, W.M.G.M van (1992) Isolation and quantitative pyrolysis mass spectrometry of dissolved chlorolignosulphonic acids: Application to pulp mill effluents, Rhine water and drinking water. Academische Proefschrift, Publ. University of Amsterdam 165pp 
Loon, W.M.G.N. van, Pouwels, A.D., Veenendaal, P. \& Boon, J.J. (1990) Ultrafiltration and pyrolysis gas chromatography mass spectrometry of chlorolignins in pulp mill effluent. Intern. J. Environmental Analytical Chemistry 38: 255-264

Lovblad, R. \& Malmstrom, J. (1994) Biological effects of kraft pulp mill effluents- a comparison between ECF and TCF pulp production. Proceedings 1994 International Non-chlorine Bleaching Conference, Amelia Island, Fla. USA

Lowell, R.B., Culp, J.M. \& Wrona, F.J. (1995) Stimulation of increased short term growth and development of mayflies by pulp mill effluent. Environmental Toxicology and Chemistry 14 (9): 1529-1541

Malinen, R., Wartiovaara, I., Valttila, O. \& Anttila, S. (1994) Scenario analysis of pulp manufacture in Finland to the year 2010. Water Science and Technology 29 (5-6): 19-31

Manolescu, D.R., Fuhr, B. \& Lee, T.W.K. (1995) Pilot work advances zero effluent bleaching technology. Proc. 1995 International NonChlorine Bleaching Conference, March 5-9, 1995, Amelia Island Florida, 21pp

Martin, V.J.J., Burnison, B.K., Lee., H. \& Hewitt, L.M. (1995) Chlorophenolics from high molecular weight chlorinated organics isolated from bleached kraft mill effluents. Holzforschung 49 (5): 453-461

McDonough, T. (1992) Bleaching Agents (Pulp and Paper) In: Volume 4. Grayson, M. (Ed). Kirk-Othmer Encyclopedia of Chemical Technology, 4th Edition. Publ. John Wiley \& Sons, New York. pp301-311

McKague, A.B., Kolar, M.-C. \& Kringstadt, K.P. (1988) Nature and properties of some chlorinated, lipophilic, organic compounds in spent liquors from pulp bleaching. 1. Liquors from conventional bleaching of softwood kraft pulp. Environmental Science \& Technology 22 (5): 523-526

McKague, A.B., Kolar, M.-C. \& Kringstadt, K.P. (1989) Nature and properties of some chlorinated, lipophilic, organic compounds in spent liquors from pulp bleaching. 2. Environmental Science \& Technology 23 (9): 1126-1129

McKague, A.B., Bradley, D., Meier, H.P., Monteith, D. \& Betts, J.L. (1990) Chloroacetones in pulp mill chlorination stage effluents . Environmental Toxicology and Chemistry 9: 1301-1303

Metcalfe, C.D., Nanni, M.E. \& Scully, N.M. (1995) Carcinogenicity and mutagenicity testing of extracts from bleached kraft mill effluents, Chemosphere 30 (6): $1085-1095$.

Mielisch, H.J., Odermatt, J., Kordsachia, O. \& Patt, R. (1995) TCF bleaching of kraft pulp: Investigation of the mixing conditions in an MC ozone stage. Holzforschung 49 (5): 445-452

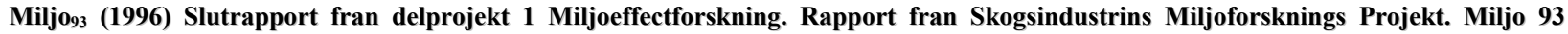
Rapprt nr.79 p43

Minor, J. (1982) Pulp. In: Volume 19. Grayson, M. (Ed). Kirk-Othmer Encyclopedia of Chemical Technology. 3rd Edition. Publ. John Wiley \& Sons, New York. pp379-419

Munkittrick, K.R., Van der Kraak, G.J., McMaster, M.E., Porrt, C.B., Van der Heuvel, M.R. \& Servos, M.R. (1994) Survey of receivingwater environmental impacts associated with discharges from pulp mills. 2. Gonad size, Liver size, Hepatic EROD activity and plasma sex steroid levels in white sucker. Environmental Toxicology 13 (7): 1089-1101

Myreen, B. (1994) Pulp and paper manufacture in transition. Water Science and Technology 29 (5-6): 1-9

Nielson, A.H., Allard, A.-S., Hynning, P.-A. \& Remberger, M. (1991) Distribution, fate and persistence of organochlorine compounds formed during production of bleached pulp. Toxicology and Environmental Chemistry . 30: 3-41

O'Connor, B.I., Kovacs, T.G., Voss, R.H., Martel, P.H., Van Lierop, B. (1993) A laboratory assessment of the environmental quality of alternative pulp bleaching effluents. EUCEPA International Environmental Symposium Proceedings, Paris, 27-29 April 1993 pp273-297

Owens, J.W. (1991) The hazard assessment of pulp and paper effluents in the aquatic environment: A review. Environmental Toxicology and Chemistry 10: 1511-1540

Owens, J.W., Swanson, S.M. \& Birkholz, D.A. (1994) Bioaccumulation of 2,3,7,8- tetrachlorodibenzo-p-dioxin 2,3,7,8tetrachlorodibenzofuran and extractable organic chlorine at a bleached-kraft mill site in a Northern Canadian river system. Environmental Toxicology and Chemistry 13 (2): 343-354

Palm, H. \& Lammi, R. (1995) Fate of pulp mill organochlorines in the Gulf of Bothnia Sediments. Environmental Science and Technology 29 (7): 1722-1727

Pellinen, J. Ruokolainen, M., Makela, P. \& Taskinen, J. (1994) Organic halogen compounds, EOX, in mussels from a clean lake and a pulp mill recipient. Chemosphere 29 (7): 1515-1526 
PPI (1991) Annual Review. Pulp \& Paper International, July 1991

PPI (1993) Annual Review. Pulp \& Paper International, July 1993

PPI (1994) Annual Review. Pulp \& Paper International, July 1994

PPI (1995) Annual Review. Pulp \& Paper International, July 1995

Rantio, T. (1995) Chlorinated cymenes in the effluents of two Finnish pulp mills in 1990-1993. Chemosphere 31 (6): $3413-3423$

Rantio, T. (1996a) Chlorohydrocarbons in pulp mill effluent and the environment II: Chlorocymenes and chlorocymenenes. Chemosphere 32 (2): 239-252

Rantio, T. (1996b) Chlorohydrocarbons in pulp mill effluent and the environment III: Persistent chlorhydrocarbon pollutants. Chemosphere 32 (2): 253-265

Rao, S.S., Burnison, B.K., Rokosh, D.A. \& Taylor, C.M. (1994) Mutagenicity and toxicity assessment of pulp mill effluent. Chemosphere 28 (10): 1859-1870

Rappe, C. \& Wagman, N. (1995) Trace Analysis of PCDDs and PCDFS in unbleached and bleached pulp samples. Organohalogen Compounds 23: $377-382$

Rapson, W.H. \& Strumila, G.B. (1979) Chlorine Dioxide Bleaching. Chapter 6 In: Singh, R.P. [Ed] The Bleaching of Pulp 3rd Edition. Publ. Tappi Press pp113-157

Reeve, D.W. (1996a) Introduction to the Principles and Practice of Pulp Bleaching. Section 1, Chapter 1 In: Dence, C.W. \& Reeve, D.W. [Eds] Pulp Bleaching: Principles and Practice. Tappi Press, Atlanta pp2-24

Reeve, D.W. (1996b) Chlorine Dioxide in Bleaching Stages. Section 4, Chapter 8 In: Dence, C.W. \& Reeve, D.W. [Eds] Pulp Bleaching: Principles and Practice. Tappi Press, Atlanta pp379-394

Reeve, D.W, Weishar, K.M. \& Li, L. (1995) Process modifications to decrease organochlorine formation during chlorine dioxide delignification. J. Pulp \& Paper Science 21 (6): 197-202

Ricketts, D. (1994) Cost analysis: Closing the bleached kraft mill. Pulp and Paper International Special Editorial Supplement "Closing the Loop: Engineering the Effluent Free Mill. Page S19

RSAES (1989) Chlorine and chlorine products: Manufacture utilisation and environmental aspects. IVA Report No: 370. Publ. Royal Swedish Academy of Engineering Sciences 44pp

Robinson, R.D., Carey, J.H., Solomon, K.R., Smith, I.R., Servos, M.R. \& Munkittrick, K.R. (1994) Survey of receiving-water environmental impacts associated with discharges from pulp mills. 1. Mill characteristics, receiving-water chemical profiles and lab toxicity tests. Environmental Toxicology and Chemistry 13 (7): 1075-1088

Rosenberg, C., Kontstas, H., Jappinen, P., Tornaeus, J., Hesso, A. \& Vainio, H. (1994) Airborne chlorinated dioxins and furans in a pulp and paper mill. Chemosphere 29 (9-11): 1971-1978

Rosenberg, C., Kontstas, H., Tornaeus, J., Mutanen, P., Jappinen, P., Vainio, H., Patterson, D.G. \& Needham, L.L. (1995) PCDD/PCDF levels in the blood of workers at a pulp and paper mill. Chemosphere 31 (8): 3933-3944

Rosemarin, A., Lehtinen, K.-J. \& Notini, M. (1990) Effects of treated and untreated softwood pulp mill effluents on Baltic Sea algae and invertebrates in model ecosystems. Nordic Pulp and Paper Journal 103: 83-87

Rosemarin, A., Jehtinen, K.-J., Notini, M. \& Mattsson, J. (1994) Effects of pulp mill chlorate on Baltic Sea Algae. Environmental Pollution 85: 3-13

Sandstrom, O. (1994) Incomplete recovery in a fish coastal community exposed to effluent from a modernised Swedish bleached kraft mill. Canadian Journal of Fisheries and Aquatic Science 51: 2195-2202

Saunamaki, R., Jokinen, K., Jarvinen, R. \& Savolainen, M. (1991) Factors affecting the removal and discharge of organic chlorine compounds of activated sludge treatment plants. Water Science \& Technology 24 (3-4): 295-307

Schell, J.D., Campbell, D.M. \& Lowe, E. (1993) Bioacumulation of 2,3,7,8-tetrachloro dibenzo-p-dioxin in feral fish collected from a bleach-kraft paper mill receiving stream. Environmental Toxicology and Chemistry 12: 2077-2082

Servos, M.R., Huestis, S.Y., Whittle, D.M., Kraak, G.J.van der \& Munkittrick, K. (1994) Survey of receiving water environmental impacts associated with discharges from pulp mills 3. Polychlorinated dioxins and furans in muscle and liver of white sucker (Catostomus 
commersoni). Environmental Toxicology and Chemistry 13 (7): 1103-1115

Shelley (1990), Chlor-alkali to work for "Industrial Ecosystem". Special Report, 8 October 1990, European Chemical News 55: 20-21

Sierra-Alvarez, R. \& Tjeerdsma, B.F. (1995) Organosolv pulping of wood from short rotation intensive culture plantations. Wood and Fiber Science 27 (4): 395-401

Sleiderink, H.M., Beyer, J., Everaarts, J.M. \& Boon, J.P. (1995a) Influence of temperature on cytochrome P450 1A in dabLimanda limanda) from the Southern North Sea: REsults from field surveys and a laboratory study. Marine Environmental Research 39: 67-71

Sleiderink, H.M., Oostingh, I., Goksoyr, A. \& Boon, J.P. (1995b) Sensitivity of cytochrome P450 1A induction in dab (Limanda limanda) of different age and sex as a biomarker for environmental contaminants in the Southern North Sea. Archives of Environmental Contamination and Toxicology 28: 423-430

Sleiderink, H.M., Beyer, J., Scholtens, E., Goksoyr, A., Niewenhuize, J., Van Liere, J.M., Everarrts, J.M. \& Boon, J. (1995c) Influence of temperature and polyaromatic contaminants on CYP 1A levels in North Sea dab (Limanda limanda). Aquatic Toxicology 32: 189-209

Smith, T.J., Wearne, R.H. \& Wallis, A.F.A. (1994a) Preparation and properties of chloro-3-methoxycatechols- components of pulp bleaching effluents. Chemosphere 28 (5): $911-920$

Smith, T.J., Wearne, R.H. \& Wallis, A.F.A. (1994b) Preparation of chlorosyringols and chloropyrogallols- components of pulp bleaching effluents. Chemosphere 28 (5): $921-930$

Smith, T.J., Wearne, R.H. \& Wallis, A.F.A. (1994c) Characteristics of the chlorinated organic substances in filtrates from bleaching of oxygen delignified eucalypt kraft pulp. Water Science and Technology 29 (5-6): 61-71

Smook, G.A. (1989) Overview of the pulp and paper industry from a chemical industry perspective. Journal of Chemical Technology and Biotechnology 45:15-27

Sodergren, A. \& (1989) [Editor] Biological Effects of Bleached Pulp Mill Effluents. Swedish Environmental Protection Board Report No: 3558. 139pp

Sodergren, A. (1993) [Editor] Bleached Pulp Mill Effluents: Composition, Fate and Effects in the Baltic Sea. Swedish Environmental Protection Agency Report No: 4047. 150pp

Sodergren, A. \& Wartiovaara, J. (1988) [Editors] Forest Industry Wastewaters- Environmental Effects. Water Science and Technology 20 (2): 210pp.

Sodra-Cell (1996) The Book about Z. Publ. Sodra-Cell, Vaxjo, Sweden 114pp

Sonnenberg, L.B. \& Nichols, K.M. (1995) Emissions of hydrochloric acid, PCDD and PCDF from the combustion of chlorine-containing kraft pulp mill bleach plant waste. Chemosphere, 31 (10): 4259-4272

Sprague, J.B. (1991) Environmentally desirable approaches for regulating effluents from pulp mills. Water Science and Technology 24 (3-4): 361-371

SPTT (1996) ECF/TCF/Closed cycle update. Simons Pulp Technologies Team, US Volume 2 (3) 4pp

Srivastava, R.K., Fargo, W.S., Sai, V.S. \& Mathur, K.C. (1988) Water quality along the Sone River polluted by the Orient Paper Mill. Water Air \& Soil Pollution 39: 75-80

Stuthridge, T.R., Campin, D.N., Langdon, A.G.,Mackie, K.L., McFarlane, P.N. \& Wilkins, A.L. (1991). Treatability of bleached kraft pulp and paper mill wastewaters in a New Zealand aerated lagoon treatment system. Water Science and Technology 24 (3-4): 309-317

Stuthridge and McFarlane, P.N. (1994) Adsorbable organic halide removal mechanisms in a pulp and paper mill aerated lagoon treatment system. Water Science \& Technology 29 (5-6): 195-208

Suntio, L.R., Shiu, W.Y. \& Mackay, D. (1988) A review of the nature and properties of chemicals present in pulp mill effluents. Chemosphere 17 (7): 1249-1290

Svensson, B.G., Nilsson, A., Hansson, M., Rappe, C., Akesson, B. \& Skerving, S. (1991) Exposure to dioxins and dibenzofurans through the consumption of fish. New England J. Medicine 324: 8-12

Swanson, S.E., Rappe, C., Malmstrom, J. \& Kringstadt, K.P. (1988) Emissions of PCDDs and PCDFs from the pulp industry. Chemosphere 17 (4): 688-691

Tana, J., Rosemarin, A., Lehtinen, K.-J., Hardig, J., Grahn, O. \& Landner, L. (1994) Assessing impacts on Baltic coastal ecosystems with mesocosm and fish biomarker tests: a comparison of new and old wood pulp bleaching technologies. Science of the Total Environment 
145: $213-234$

USEPA (1995) Profile of the Pulp and Paper Industry. United States Environmental Protection Agency, Office of Enforcement and Compliance Assurance. EPA 310-R-95-015 128pp + Appendices

Walden, C.C. (1976) The toxicity of pulp and paper mill effluents and corresponding measurement procedures. Water Research 10: 639664

Waldmeyer, T. (1957) The Treatment of Papermill Wastes. In: Isaac, P.C.G. (Ed) The Treatment of Trade-Waste Waters and the Prevention of River Pollution. Publ. University of Durham, King's College. pp215-226

Wienecke, J., Kruse, H., Huckfeldt, U., Eichoff, W. \& Wassermann, O. (1995) Organic compounds in the flue gas of a hazardous waste incinerator. Chemosphere 30 (5): 907-914

Wesen, C., Carlberg, G.E. \& Martinsen, K. (1990) On the identity of chlorinated organic substances in aquatic organisms. Ambio 19 (1): 36-38

Whittemore, R.C., LaFleur, L.E., Gillespie, W.J., Amendola, G.A. \& Helms, G. (1990) USEPA/Paper industry co-operative study: The 104 mill study. Chemosphere 20: 1625-1632

Whittle, D.M., Mageau, C., Duncan, R.K., Sergeant, D.B., Nassichuk, M.D., Morrisson, J. \& Piuze, J. (1993) Canadian national dioxin sampling program: dioxins and furans in biota near 46 pulp and paper mills using the chlorine bleaching process. Chemosphere 27: 279286

Wigilius, B., Boren, H., Grimvall, A., Carlberg, G.E., Hagen, I. \& Brogger, A. (1988) Impacts of bleached kraft mill effluents on drinking water quality. Science of the Total Environment 74: 75-96

Wulff, F. \& Rahm, L. (1993) Accumulation of chlorinated organic matter in the Baltic Sea from 50 years of use- A threat to the environment. Marine Pollution Bulletin 26 (5): 272-275

Zender, J.A., Stuthridge, T.R., Langdon, A.G., Wilkins, A.L., Mackie, K.L. \& McFarlane, P.N. (194) Removal and transformation of resin acids during secondary treatment at a New Zealand Bleached Kraft pulp and paper mill. Water Science and Technology 29 (5-6): 105-121 